IZA DP No. 6708

Leisure Inequality in the United States: 1965-2003

Almudena Sevilla

J. Ignacio Gimenez-Nadal

Jonathan I. Gershuny

July 2012 


\title{
Leisure Inequality in the United States: 1965-2003
}

\author{
Almudena Sevilla \\ Queen Mary University of London \\ and IZA
}

J. Ignacio Gimenez-Nadal

University of Zaragoza

\author{
Jonathan I. Gershuny \\ CTUR, University of Oxford
}
Discussion Paper No. 6708
July 2012

IZA
P.O. Box 7240
53072 Bonn
Germany

Phone: +49-228-3894-0

Fax: +49-228-3894-180

E-mail: iza@iza.org

\begin{abstract}
Any opinions expressed here are those of the author(s) and not those of IZA. Research published in this series may include views on policy, but the institute itself takes no institutional policy positions.

The Institute for the Study of Labor (IZA) in Bonn is a local and virtual international research center and a place of communication between science, politics and business. IZA is an independent nonprofit organization supported by Deutsche Post Foundation. The center is associated with the University of Bonn and offers a stimulating research environment through its international network, workshops and conferences, data service, project support, research visits and doctoral program. IZA engages in (i) original and internationally competitive research in all fields of labor economics, (ii) development of policy concepts, and (iii) dissemination of research results and concepts to the interested public.
\end{abstract}

IZA Discussion Papers often represent preliminary work and are circulated to encourage discussion. Citation of such a paper should account for its provisional character. A revised version may be available directly from the author. 


\section{ABSTRACT}

\section{Leisure Inequality in the United States: 1965-2003 *}

This paper exploits the complex sequential structure of the diary data in the American Heritage Time Use Study (AHTUS) and constructs three classes of indicators that capture the quality of leisure ('pure leisure', 'co-present leisure' and 'leisure fragmentation') to show that the relative growth in leisure time enjoyed by less-educated individuals documented in previous studies has been accompanied by a relative decrease in the quality of that leisure time. These results are not driven by any single leisure activity, such as time watching television. Our findings may offer a more comprehensive picture of inequality in the US and provide a basis for weighing the relative decline in earnings and consumption for the less educated against the simultaneous relative growth of leisure.

JEL Classification: C13, C23, D13, J12, J16, Z13

Keywords: leisure, inequality, income, wages, consumption, time-use, happiness

Corresponding author:

Almudena Sevilla

Queen Mary University of London

Department of Business and Management

Francis Bancroft Building

Mile End Road

London E1 4NS

United Kingdom

E-mail: a.sevilla@qmul.ac.uk

\footnotetext{
* The authors would like to express their thanks for the financial support provided by the Spanish Ministry of Education and Science (Project SEJ2005-06522) and the Economic and Social Research Council (Grant number RES-060-25-0037). The views expressed in this paper are solely those of the authors and may not reflect the views of the creators or funders of AHTUS or the collectors of the original surveys harmonized in this data set.
} 
"The basis on which good repute in any highly organized industrial community ultimately rests is pecuniary strength; and the means of showing pecuniary strength, and so of gaining or retaining a good name, are leisure and a conspicuous consumption of goods"

"The Theory of the Leisure Class" (Chapter 4), Thorstein Veblen (1953)

\section{INTRODUCTION}

The distribution of leisure in the US over the last four decades contrasts remarkably with the evolution of inequality in wages and expenditure over the same period of time. Despite growing wage and expenditure inequality in the US (e.g., Attanasio and Davis 1996; Autor and Katz 1999; Krueger and Perri 2006), the cross-sectional distribution of leisure time expanded over the last 40 years (Aguiar and Hurst 2007). While the level of leisure in 1965 was roughly equal across educational groups, the subsequent increase in leisure was largest for low educated adults. Highly educated individuals now have substantially less leisure time than low educated individuals. ${ }^{1}$ This variation in leisure across educational levels has also been documented by Gershuny (2009a), who finds a reversal of the previously negative relationship between human capital and work time in 11 developed economies.

In this paper we look inside the black box of leisure time, exploiting the rich information in the time-use diary data to construct three classes of indicators that capture the quality of leisure. Most studies using the AHTUS focus their analysis merely on the 'primary activity' field of the diary instrument. We deploy more of the rich diary information in the US time-use series'secondary activities' and 'co-presence'-to measure the distribution of quantity and quality of leisure. These diary records allow us to look at the simultaneity of leisure activities with nonleisure activities, the presence of other individuals while the respondent is engaging in a leisure activity, and the extent to which leisure events are interrupted by other activities (i.e., 'pure leisure', 'co-present leisure' and 'leisure fragmentation').

The majority of our leisure quality indicators show that, despite increases in the quantity of leisure over this period (as reported by Aguiar and Hurst (2007) and others), the quality of leisure decreased for all groups. This decline in leisure quality is consistent with the results using instant enjoyment data showing declines in the time spent in the sorts of activities labeled enjoyable and engaging forms of leisure (Krueger 2007). Despite general increases in leisure time, Americans

\footnotetext{
${ }^{1}$ A similar pattern is found by Costa (2000), who documents that low-wage workers reduced their market work hours relative to high-wage workers between 1890s and 1991.
} 
report feeling increasingly harried now compared to forty years ago (e.g., Hamermesh and Lee 2007; Robinson and Godbey 1997; Schor 1993). Our findings may help explain this paradox.

More directly relevant to the focus of this paper is a comparison across educational groups over time. It emerges that qualitative differences in leisure time between educational groups partially compensate for highly educated individuals now having less leisure time. Leisure increased nearly an hour per week more for low educated men than for highly educated men, and three and a half hours more for low educated women than for highly educated women. However,pure leisure (the amount of leisure time that is not 'contaminated' by other non-leisure activities) declined substantially more for low educated individuals than for highly educated individuals over the period for which we can observe it. Between 1965 and 1985 low educated men experienced a decline of one hour and 35 minutes per week - vs. 50 minutes for highly educated men. Similarly, low educated women experienced a decline in pure leisure of one hour and 50 minutes, vs. a decline of just one hour for highly educated women, over the same period. Between 1965 and 2003, leisure time spent in the company of the spouse declined one hour for men with at most a high school degree, whereas men with some college or more did not experienced a statistically significant decrease in this indicator. Similarly, also between 1965 and 2003 , low educated men and women decreased the number of hours spent in the company of other adults to a greater extent than highly educated adults. Highly educated men have also experienced a more favorable trend in leisure fragmentation than low educated men. In contrast, highly educated women, and in particular highly educated working women, have experienced a less favorable trend in leisure fragmentation than their low educated counterparts.

We find that no single leisure activity can explain the differential trends in terms of leisure quantity and quality across educational groups over this period. We show that the pattern of change of leisure quality (and quantity) across educational groups remains very similar when TV watching is not included in the definition of leisure. Other leisure activities such as 'At Home Leisure' and 'Read/Listen', which also represent a significant fraction of the total amount of leisure time, similarly fail to explain the unequal distribution of leisure quality across educational groups.

Our work expands the existing literature on measuring changes in the allocation of time in the US. The literature mainly concentrates on the study of aggregate totals of time (e.g., Ghez and Becker 1975; Juster and Stafford 1985; Robinson and Godbey 1997; and Aguiar and Hurst 2007). But introducing other dimensions of time in the analysis of inequality is crucially important. Though the scarcity of leisure time may seem analogous to income poverty, in that both reflect 
the scarcity of resources, the two concepts in fact have different historical dynamics. In a growing economy the goods constraint relaxes over time, whereas the 24 hours per day time constraint does not. It is possible, however, that the time-budget constraint might instead be ameliorated by adjusting the quality of leisure over time.

This paper also contributes to a recent broadening of focus from production to the measurement of well-being. Stiglitz, Sen and Fitoussi (2009) among others have recently proposed a broad range of measures of household economic activity to evaluate quality of life, such as time spent in leisure and the instant enjoyment of leisure activities. Our objective indicators of leisure quality may provide an additional basis for interpreting well-being inequality in the US and for weighing the relative growth of leisure for the less educated against the simultaneous decline in relative wages and consumption.

This paper is organized as follows. The next Section describes the time-use datasets used in the analysis and the the conceptualization ofthe quantity of leisure, and presents the theoretical and empirical underpinnings for our leisure-quality indicators. We then show the main results, and looks more deeply into how the nature of specific leisure activities may have contributed to the differential trends in the quantity and quality of leisure. The final Section concludes.

\section{THE AMERICAN HERITAGE TIME USE STUDY (1965-2003)}

We use the American Heritage Time Use Study (AHTUS) in our main analysis. The AHTUS is a harmonized dataset that covers five decades, from 1965 to 2003, over five time-use surveys. Appendix A describes the main sample in our analysis and Table A1 in Appendix A shows the five surveys in the AHTUS as well as the harmonization exercise. The main instrument of all the surveys is an activity diary in which respondents record what they do for a consecutive period of 24 hours. For each respondent there is a diary file made up of a sequence of episodes over the 24 hour span, which allows the inclusion of harmonized information on secondary activity, and who else is present at the time of the activity. The AHTUS also allows us analyze episode files rather than aggregated files.

\section{The Quantity of Leisure}

The conceptualization of leisure, and of time use categories in general, is usually driven by a systematic, principle-driven approach of distinguishing means vs. ends .The so-called third person criterion excludes activities that might be carried out by some third party without losing the intended utility for the final consumer. Unfortunately, the third person criterion involves 
questionable assumptions such that the enjoyment derived from work can legitimately be ignored, and that all leisure is enjoyable. ${ }^{2}$ Certain activities, such as sleeping, eating, personal and medical care, or resting, do not fall comfortably into the means vs. ends classification. These activities cannot be purchased in the market, but they may not be considered leisure in the sense that they are necessary for life. Nonetheless, some variation in the time spent in these activities may result from conscious choice. Biddle and Hamermesh (1990) show that sleep time responds to economic incentives such as the wage. Decreasing marginal utility of sleep (and of other consumption activities) is indeed shown by Gershuny (2009b) useing (subsequent) diary reports of enjoyment.

Rather than trying to resolve this debate on theoretical grounds, we adopt an empirical approach, exploring four commonly used, nested, definitions of leisure, ranging from the narrow (which includes activities designed to yield direct utility such as entertainment, socializing, active recreation, and general relaxation), to the broad (time spent neither in market production nor in nonmarket production). The various measures tell a consistent story, so for the sake of brevity we present here only the results regarding our narrowest measure of leisure, i.e., hours per week devoted to all activities that we cannot pay somebody else to do for us and that are not biological needs (e.g., Walker and Gauger 1973; Hawrylyshyn 1976,1977; Burda, Hamermesh and Weil 2008) ${ }^{3}$

Among the activities included in the leisure category are watching television, sport activities, general out-of-home leisure, and socializing. We exclude voluntary activities from our main definition of leisure, since it classes as work under the third person criterion (see Hawrylyshyn 1976). Though the classification of time-use activities changes over time, and some activities disappear and new activities emerge (just as in the case of expenditure diary categories), the AHTUS nevertheless provides comparable leisure activities for the different years so that it is still possible to run meaningful comparisons over time of broad time-use categories such as leisure. ${ }^{4}$

\section{The Quality of Leisure}

\footnotetext{
${ }^{2}$. One quarter of time that would be considered leisure according to the conventional implementation of the third person criterion, and one third of what would conventionally be considered work, is unexpectedly placed by the diarists (Gershuny 2009b).

${ }^{3}$ Results for the other definitions of leisure are available upon request.

${ }^{4}$ Although there are some activities coded in AHTUS which were not coded as such in the original surveys- because the coding of activities was different-, we have paid particular attention to having comparable activities defined for the different years. The only exception is computer use, which is not coded as such in surveys 1965 and 1975 reflecting the fact that there were no personal computers at the time. Excluding computing out of our definition of leisure would not have been an option, since leisure in the latter years would have been underreported. For more information refer to the "concordance files" at http://www.timeuse.org/files/cckpub/AHTUS-USAConcordanceFiles-20091202.xls and the "Variables in the Diary Files" Table at http://www.timeuse.org/files/cckpub/AHTUS-Variable-In-Time-Diary-Files20100109.pdf.
} 
There are different ways of assessing the quality of leisure. One methodology is to use selfreported measures of how enjoyable activities are, in the spirit of the process benefits and experienced utility literature. Juster and Stafford (1985) define process benefits as the 'direct subjective consequences from engaging in some activities to the exclusion of others'. ${ }^{5}$ Going back to the earliest conceptions of utility, from Jeremy Bentham through Francis Ysidro Edgeworth and Alfred Marshall, the concept of experienced utility has been proposed more recently by Kahneman et al. (2004) to refer to a 'continuous hedonic flow of pleasure or pain'.

Both lines of research use time-use diaries together with information on enjoyment to assess individuals' subjective well-being. The process benefits approach uses Activity Enjoyment Ratings, where respondents are to rate on a scale from 0 to 10 how much they generally enjoyed a type of activity (e.g., Juster and Stafford 1985). The information gathered this way offers a global and retrospective interpretation of feelings about activities, although they may not serve as a good predictor of the instantaneous satisfaction experienced in any given instance of the activity (Gershuny and Halpin 1996). The experienced utility literature has proposed the Experience Sampling method as a superior way for collecting objective instantaneous enjoyment data. As opposed to the Activity Enjoyment Ratings, the Experience Sampling method collects information on hedonic experiences (or instant enjoyment) in real time. It has however never been applied to a representative population sample because it is extremely burdensome for the respondent. ${ }^{6}$ Alternative methods of collecting data on hedonic experiences, such as the conventional yesterday diary used in time budget surveys (Szalai 1972) or the Day Reconstruction Method (Kahneman et al. 2004) are less costly to implement. Both methods collect information on how the respondent experienced all or some of the activities he or she engaged in during the previous day, as described by a time-use diary. ${ }^{7}$

\footnotetext{
5 'For instance, how much an individual likes or dislikes the activity 'painting one's house,' in conjunction with the amount of time one spends in painting the house, is as important determinant of well-being independent of how satisfied one feels about having a freshly painted house." (Juster and Stafford 1985:pp.113-131)

${ }^{6}$ Experience sampling was developed to collect information on people's reported feelings in real time in natural settings during selected moments of the day (Csikszentmihalyi 1990; Stone and Schiffman 1994). Participants in ESM carry a handheld computer that prompts them several times during the course of the day (or days) to answer a set of questions immediately, such as their physical location, the activities in which they were engaged just before they were prompted or the people with whom they were interacting. They also report their current subjective experience by indicating the extent to which they feel the presence or absence of various feelings, such as feeling angry, happy, tired and impatient (Steptoe, Wardle and Marmot 2005; Kahneman and Krueger 2006).

${ }^{7}$ The Day Reconstruction Method has been used for example in the collection of the Princeton Affect and Time Survey (PATS). Here respondents were asked to reconstruct the previous day by completing a short diary. Then three 15minute intervals were randomly selected from the non-sleeping portion of the diary, and respondents were then asked the extent to which they experienced six different feelings (pain, happy, tired, stressed, sad, and interested) during each interval (Krueger 2007). Previously, the otherwise similar "yesterday diary" approach was used to collect information on the levels of instant enjoyment for all the episodes (not just three) in the diary as in the examples from the UK and
} 
Whereas there is historical information on time-use diary records from 1965 for the US, only one survey contains information about instant enjoyment for a nationally representative sample. We thus adopt a complementary approach to the above literature and exploit the rich information in the diary to construct three classes of leisure quality indicators that emerge independently from different strands in the socio-economic and psychological literature. ${ }^{8}$ The relationship between quality of leisure and some of these indicators, in particular those related to the presence of other individuals while the respondent engages in leisure activities, has already been directly established using instant-enjoyment data of the sort proposed by the process-benefits and experienced-utility literature. Using the AHTUS and a closely analogous UK dataset we present a simple validation exercise of all our indicators by analysis of the available direct evidence of the enjoyability of activities in Appendix B. The validation exercise suggests that these indicators are capable of conveying important information about leisure quality that cannot be explained by the type of leisure activity alone. Even though we lack additional direct information about how much respondents enjoy engaging in a given activity for the decades being analyzed, our indicators seem to be good instruments for assessing trends in the quality of US leisure time.

\section{Pure Leisure}

The first class of indicator is related to activity density. Respondents frequently engage in more than one single activity at the same time. The secondary activity is an activity simultaneous with another identified by the diary respondent as the "main activity", which may in some way complement or qualify it. The underlying rationale behind this indicator is that leisure activities with no "distracting" accompanying activities will be associated with a higher utility than leisure activities accompanied by a secondary activity (see Bittman and Wajcman 2000; Mattingly and Bianchi 2003). ${ }^{9}$ We define pure leisure as leisure that is reported as primary activity whose secondary activity is not market work, home production or personal care, and analyze the

the US AHTUS in Appendix B. Unlike the PATS, these surveys collect one dimension of instant enjoyment, which is scaled from 5 to 0 and 0 to 10 respectively. Knabe et al. (2010) uses both types of measures and reach the same conclusions with the two types of measures.

${ }^{8}$ An alternative method would require imputations of enjoyment-levels for the other survey years (either at the activity level as in Krueger (2007) or at the individual level). A potential limitation to this method (see Krueger 2007) is that it maintains the nature of activities relatively constant, not only over time, but also across educational groups. This latter point is particularly relevant in the current context, as different groups of individuals may rank the same activity differently, and the mix of these responses may change over time. Results from our validation exercise in Appendix B suggest that our indicators can still be used as a good proxy for leisure quality. We thus leave investigating this alternative method for future research.

${ }^{9}$ For example, Gimenez-Nadal and Ortega-Lapiedra (forthcoming) shows that the leisure of self employed men is more often intertwined with market work activities, leading self-employed men to report higher levels of time stress. 
proportion of pure leisure out of total leisure. Pure leisure cannot be analyzed for 1993 and 2003 since these surveys collected no separately identified secondary activities.

\section{Co-present leisure}

The second class of indicators relates to with whom the leisure activity is performed. Consider first leisure with the spouse (or partner). The concept of leisure with spouse draws from the empirical evidence found in the socio-economic literature on spouses' synchronization of work and leisure activities. Sullivan (1996a) uses a 1985 UK time-use survey, a diary survey including instantaneous enjoyment diary information, to show that partners report higher levels of satisfaction when they synchronize their working schedules (and thus maximize the potential time they can spend in leisure activities together). ${ }^{10}$ Hamermesh (1999), Hallberg (2003), and Jenkins and Osberg (2005) follow Sullivan (1996a) in finding that synchronization of leisure activities between partners is indeed greater than random male-female pairing would predict. We thus use information on whether leisure as primary activity is carried out while the spouse/partner is present, to calculate the percentage of total leisure time of leisure with spouse (or partner) as an indicator of leisure quality. Because of demographic changes regarding the propensity to marry, which has fallen in the US during this time period due to the delay in the age of marriage and increase in divorce rates, we restrict the sample to those individuals with a partner when computing this indicator. The indicator of leisure with spouse can be constructed for all the surveys except for those in 1985 and 1993, where information on spouse or partner co-presence was not gathered.

The second indicator in this class uses information on whether another adult was present during a leisure activity to construct the percentage of total leisure that constitutes leisure with adults, i.e. leisure time spent with adults (neither alone nor in the presence of children). ${ }^{11} \mathrm{We}$ can calculate this for the 1965, 1975, and 2003 surveys. There is evidence from instant enjoyment data, which suggests that individuals report higher levels of instant satisfaction from activities

\footnotetext{
${ }^{10}$ There is extensive evidence pointing toward positive assortative mating along education (Lam 1988; Blosfeld and Timm 2003) and it thus may well be that highly educated individuals have a higher preference for spending leisure time with a spouse, precisely because the spouse is also highly educated. This hypothesis does not seem to be ratified by the results shown in Appendix B however. We find that individual's enjoyment of leisure time when accompanied by the spouse is greater regardless of educational class.

${ }^{11}$ The category "other adult" is considered to be the spouse or partner, other adult from the household, a shop or professional worker, a co-worker, a person well-known, and other (adult) person present. Unfortunately, the AHTUS lacks comparable information across years on whether a child is present, and thus comparisons along these lines are not possible.
} 
done in the company of others than by themselves (e.g., Kahneman et al. 2004; Helliwell and Putnam 2005). In fact the adverse effects of isolation on mental health are well-known in the epidemiological and psychological literature (e.g., House, Landis and Umberson 1988; Berkman and Glass 2000; Putnam 2000; Eng et al. 2002; Berkman et al. 2004; Singh-Manoux and Marmot 2005). Similarly, the positive externalities of synchronicity not just in leisure, but also in market work and household labor, have been often pointed out in the economics literature (e.g., Weiss 1996). Few studies have tried to identify exogenous determinants of coordination. For example, public holidays have been found to be welfare enhancing, not only by increasing the amount of leisure to each individual, but also by increasing the coordination of leisure activities among individuals (e.g., Mers and Osberg 2006). Similarly, Hamermesh, Myers and Pocock (2008) find that an exogenous shock to time in one area, due to daylight-saving time, leads its residents to change their work schedule so as to coordinate their other (leisure) activities with those in adjacent areas.

\section{Leisure fragmentation}

The third class of indicator is leisure activity fragmentation. For a given amount of leisure time, those individuals with more fragmented leisure may be justifiably more rushed and stressed. To measure the fragmentation of leisure we use the number of leisure intervals during the diary day. An interval is defined as an uninterrupted period of time when the individual is engaged in one of these four main activities: market work, personal care, home production and leisure. We then define a leisure interval as that time interval where the main activity is leisure (regardless of whether the interval contains two or more different leisure episodes). ${ }^{12}$

The number of leisure intervals can thus only give a partial picture of leisure fragmentation. In particular, the difference in the change in the number of leisure intervals for low and high educated individuals does not necessarily imply a difference in the fragmentation of leisure between the two groups because leisure time evolved differently for each group. To address this caveat, we also report the average duration of leisure intervals, defined as the individual's amount of leisure (in minutes per day) divided by the individual's number of leisure intervals.

It is important to note that the switch of method from the diary the diarist sees $(1965,1975$ and 1985) to the telephone diary (1993 and 2003) seems to have resulted in a decline in the number of episodes in recent surveys. Also for the earlier studies (1965, 1975 and 1985)

\footnotetext{
12 The diary survey is organized in episodes. Thus, two consecutive leisure activities are considered to be different episodes (i.e. reading and cycling), but these consecutive leisure episodes are considered to be the same leisure interval according to our definition.
} 
respondents are automatically assigned a new episode with a change of location, main activity or secondary activity, which results in these surveys having more episodes. To the extent that low and highly educated individuals are affected by data collection methods in the same way, this artificial decrease in the mean number of episodes over the five surveys should not affect the relative trends in leisure quality reported here. Nonetheless, we acknowledge that absolute trends in the number of leisure intervals and the duration of leisure intervals over this period might also be capturing survey design changes as well as genuine changes in the fragmentation of activities. We thus define the normalized number of intervals as the number of intervals divided by the total number of intervals in the survey, and the normalized average duration of leisure intervals as the total amount of leisure divided by the normalized number of intervals. We discuss additional evidence from these normalized measures below.

\section{Summary Statistics}

Table 1 shows descriptive statistics for the indicators of quantity and quality of leisure over the sample period by education group for men and women separately. ${ }^{13}$ We perform the analysis for highly and low educated individuals separately. A highly educated individual is defined as having more than a high school degree or GED equivalent, i.e., some college or a college degree or more (13 or more years of schooling). Low educated individuals are those with up to 12 years of schooling, i.e., with at most a high school degree.

The first row in Panel A and B of Table 1 shows similar trends in the quantity of leisure to those found in previous research. ${ }^{14}$ Men's average hours of leisure per week exhibit a statistically significant increase over the period of reference, from 28 hours of leisure per week in 1965 to 33 hours and 30 minutes of leisure per week in 2003. Women's leisure time follows a similar pattern, increasing (on average) by three hours and 30 minutes per week over the relevant period from 27 hours in 1965. The increases in leisure time are greater for low educated individuals. At the beginning of the period low educated men started with three hours and 20 minutes more of leisure than highly educated men, and low educated women started with 50 minutes more of

\footnotetext{
${ }^{13}$ We use the weights provided in the AHTUS. These weights account for population/sample distribution by age group and sex, and provide an even distribution of the days of the week. All cases with missing basic information or bad diaries are 0-weighted, and thus are excluded from the analysis. Further information on these weights can be found in the AHTUS codebook at http://www.timeuse.org/ahtus/documentation/docs/pdf/Codebook.pdf.

${ }^{14}$ Aguiar and Hurst (2007) find that leisure for men increased by 6-8 hours per week for men and 4-8 hours per week for women over the period 1965-03. Burda et al. (2008) find a decrease in the amount of leisure time in 2003 with respect to 1985 of 13.3 and 2.7 minutes per day for men and women respectively. Differences between the two sets of results might be due to the sample used in their analysis (they use a sample of individuals between 20-74 years old).
} 
leisure than highly educated women. By the end of the period however, the differences between the two education groups had widened with low educated men and women having respectively three hours and 35 minutes, and three hours and 45 minutes more of leisure than highly educated men and women.

Between 1965 and 1985 the percentage of pure leisure decreased on average by 5 , and 5 and a half percentage points for men and women respectively. There was also a statistically significant decrease in the percentage of leisure with spouse for men between 1965 and 2003. Married men reported spending less time in the presence of the spouse over this period, reducing from an average of 57 percentage points of the time in 1965, to 53 percentage points in 2003. In contrast, married women reported to spend more leisure time in the presence of the spouse over this period, increasing from an average of 44 and a half percentage points of the time in 1965 to 49 and a half percentage points in $2003 .{ }^{15}$ The percentage of leisure with adults decreased for men and women by an average of 13 and 7 percentage points respectively between 1965 and 2003. Although raw figures show a general decrease in the number of leisure intervals for women, and an increase in the average duration of leisure intervals for both men and women, they seem to be masking the real increase in the fragmentation of leisure. Once we adjust for changes in the total number of intervals, which we believe likely is an artifact of changes in survey methodology, there is indeed an increasing trend in the normalized number of intervals for both men and women, and a decline in the normalized average duration of leisure intervals for women. ${ }^{16}$

Thus, in stark contrast with the changing amount of leisure, most of our quality indicators show declines in the quality of leisure time over this period for both men and women. Moreover, although low educated men and women started off with higher quality of leisure according to most of our indicators (with the exception of pure leisure) the differences between the two education groups narrowed over this period, as the quality of leisure decreased differentially more for low than for highly educated individuals. These trends however do not take into account sample composition effects. The average American has aged, become more educated, become

\footnotetext{
${ }^{15}$ The discrepancy between the reported leisure with spouse between married men and women is due to the fact that married women are more likely to do housework while their spouses are enjoying leisure. Fisher et al. (2007) illustrate the persistence of gender difference in the time when partners are together - when there is unpaid labor to be done during leisure time, women still remain more likely to carry out the chores (e.g., where he sits in front of the television, perhaps talking with her while she sets the table and finishes food preparation). Similarly, the different trends in this indicator between men and women are the result of women's decrease in the time devoted to household chores over these decades.

${ }^{16}$ The number of normalized intervals increased by 1.21 for men and by 3.62 for women, whereas the normalized duration of intervals increased for men by 1.35 minutes per day for men, but decreased by .82 minutes per day for women.
} 
more likely to be single, and to have fewer children since 1965. All of these changes may affect how an individual chooses to allocate his or her time, and thus controlling for demographics is also important for the analysis of the trends of the quality and quantity of leisure over time. The next section explores these trends across educational groups to examine the extent to which the quantity and quality of leisure has become more unequal between education groups, adjusted for demographic changes.

\section{TRENDS IN THE QUANTITY AND QUALITY OF LEISURE BY EDUCATIONAL STATUS}

\section{Empirical Specification}

We estimate Equation (4.1) for each education group $e$, and for men and women, separately:

$$
\mathrm{Y}_{\mathrm{it}}^{\mathrm{e}}=\alpha^{\mathrm{e}}+\beta_{\mathrm{t}}^{\mathrm{e}} D_{i t}+\gamma^{\mathrm{e}} \mathrm{X}_{i t}^{e}+\xi_{\mathrm{it}}^{\mathrm{e}}
$$

where $Y_{i t}$ is the dependent variable measuring the quantity/quality of leisure for individual $i$ in survey $t, \mathbf{D}_{\mathbf{i t}}$ is a vector of year dummies that are equal to one if the individual $i$ participated in the time-use survey conducted in year $t$ and zero otherwise. Demographic controls in the vector $\mathbf{X}_{i t}$ include the age of respondent $i$, a dummy variable that takes value one if the respondent $i$ has at least one child and zero otherwise, and dummy variables for the different days of the week (ref: Friday). The day variable is necessary, given that some of the surveys over-sample weekends for some sub-samples. ${ }^{17}$

The superscript $e$ represents our education categories. We perform the analysis for highly and low educated individuals separately, as defined in the previous section. The coefficient of interest is the $T$ year dummy coefficient $\left(\beta_{\mathrm{T}}^{\mathrm{e}}\right.$ ) for each educational category $e$, where T represents the last year for which we have information on the dependent variable (this year is 2003 for all leisure quality indicators except for our indicator of pure leisure, where $T$ is 1985). These coefficients inform us about how the quantity and quality of leisure have changed over time for each educational group, controlling for changes in key demographics.

A positive value of $\beta_{T}^{\mathrm{e}}$ when the dependent variable is the amount of leisure would indicate increases in leisure over these decades. A negative $\beta_{T}^{\mathrm{e}}$ coefficient when the dependent variables

\footnotetext{
${ }^{17}$ In all years except 1993, the time-use surveys asked respondents to report their marital status. Although our base results do not include this control (because they are unavailable for 1993), we reran all of our regressions, including marital status as an additional control, on a sample that excludes the 1993 survey. This modification did not alter the main findings of our paper and results are available upon request.
} 
are our indicators of pure leisure, co-present leisure and average duration of leisure intervals, and positive $\beta_{T}^{\mathrm{e}}$ when our dependent variable is the number of leisure intervals, would indicate decreasing quality of leisure in year $T$ with respect to 1965 . To answer the question of whether less educated individuals have lost leisure quality relative to more educated individuals over this period we compare changes in our leisure quality metrics for less educated workers and highly educated workers (i.e., Diff $=\beta_{T}^{\mathrm{e}<=12}-\beta_{T}^{\mathrm{e}>12}$ ), and also check whether the difference Diff is statistically significant.

\section{Results}

Panel A and Panel B in Table 2 show the trends in the quantity and quality of leisure for men and women controlling for demographic characteristics. Column (1) shows the coefficient $\beta_{\mathrm{T}}^{\mathrm{e}<=12}$ for low educated individuals, and Column (2) shows the coefficient $\beta_{\mathrm{T}}^{\mathrm{e}>12}$ for those individuals with at least some college education. Column (3) reports the difference between these two coefficients, $\beta_{\mathrm{T}}^{\mathrm{e}<=12}-\beta_{\mathrm{T}}^{\mathrm{e}>12}$, and inform us about the direction of the changes in leisure time and leisure quality for each education category during the relevant period (the relevant period is 1965-2003 for all indicators, with the exception of the percentage of pure leisure, which is only observed between 1965 and 1985). The p-value of this difference is reported in Column (4), and indicates whether there is a statistically significant difference in the trends in the quantity and quality of leisure between the two educational groups (the rest of the year coefficients included in the regression are available upon request).

The general picture that emerges from Table 2 is that whereas individuals with less than 13 years of schooling increased the quantity of leisure with respect to 1965 more than the college educated group, the relative quality of leisure for less educated individuals deteriorated over time. The difference in the trends between the two educational groups is generally statistically significant (Column 4).

The first row of Panel A in Table 2 shows that for men, the 1965-2003 increase in leisure time for low educated individuals is statistically significant and accounts for almost five hours and fifteen minutes per week, as indicated by the coefficient on leisure time in the year 2003 in Column (1). Low educated men increased leisure time by almost one hour more than highly educated men (Column 3), and this difference is statistically significant at the $99 \%$ level as shown in Column (4). Panel B shows a similar picture for women, although the differences across educational groups are greater. In 2003, low educated women enjoyed five and a half more hours 
per week of leisure time than in 1965, whereas highly educated women had an increase of two hours of leisure per week. The difference of three hours and a half (Column 3) between educational groups is statistically significant at the $99 \%$ level, as shown in Column (4).

The remaining rows in Columns (1) and (2) in Panel A of Table 2 show that highly educated men experienced smaller declines in the quality of leisure than less educated men. Men with some college or more experienced a statistically significant decrease of three and a half percentage points in the percentage of pure leisure between 1965 and 1985. Although they did not experience a statistically significant change in the percentage of leisure with spouse, they had a statistically significant decrease in the percentage of leisure with adults of seven percentage points between 1965 and 2003. In contrast, low educated men experienced much larger decreases in all indicators, i.e. a six percentage points decrease in pure leisure and leisure with spouse, and a decrease of 10 and a half percentage points decrease in the percentage of leisure with adults. Given that the average uncontaminated leisure time over the relevant period is of 25 hours and 45 minutes per week for low educated men, these percentages translate into losses in pure leisure of one hour and 35 minutes $(25.71 * 6.33=1.62)$ per week. Similarly, the coefficients on leisure with spouse, and leisure with adults suggests decreases of the order of one hour (17.35*5.97), and two hours and 15 minutes $(21.39 * 10.54)$ per week, respectively (the average leisure time with the spouse and leisure with other adults over the relevant period for low educated men is 17 hours and 20 minutes, and 21 hours and 35 minutes per week, respectively). For highly educated men, these percentages translate into losses in pure leisure and leisure with adults of 50 minutes $(23.54 * 3.54)$, and one hour and 20 minutes $(19.07 * 6.81)$, respectively (average uncontaminated leisure and leisure with other adults over the relevant period for highly educated men is 23 hours and 30 minutes, and 17 hours per week, respectively).

Results from raw and normalized data suggest that highly educated men have become relatively better off in terms of the fragmentation of leisure than low educated men. Highly educated men experienced a decrease in the number of leisure intervals of 0.11 leisure intervals between 1965 and 2003, while low educated men did not experience any statistically significant change. The average duration of leisure intervals also increased more for highly educated individuals (20 minutes per day), versus an increase of just 18 minutes per day for low educated men (although this difference is statistically significant only at the $90 \%$ level). Similarly, relative trends using a normalized measure of leisure intervals show that increases in the normalized number of intervals were lower for highly educated men than for low educated men, and that the 
normalized duration of leisure intervals increased for highly educated individuals but decreased for low educated individuals.

The relative quality of leisure also declined more for less educated women than for women with some college or more. We find that less educated women experienced a statistically significant decrease in the percentage of pure leisure of almost seven percentage points between 1965 and 1985, whereas highly educated women experienced a decrease of just four and a half percentage points. Because the average non-contaminated leisure time is 27 hours and five minutes per week, and 24 hours and 30 minutes per week, for low and highly educated women over this period respectively, these coefficients translate into a reduction of one hour and 50 minutes $(27.09 * 6.80)$ of non-contaminated leisure per week for low educated women, and of one hour $(24.47 * 4.35)$ of non-contaminated leisure per week for highly educated women. Restricting the sample to married women shows increases in the percentage of leisure with spouse for both educational groups between 1965 and 2003. However, highly educated women experienced a larger increase in this indicator than low educated married women (eight versus three percentage points). These coefficients suggest increases in leisure with spouse of 25 minutes (15.14*2.74), and one hour and 10 minutes $(13.94 * 8.11)$ per week for low and highly educated women respectively. The percentage of leisure with adults decreased slightly more for the highly educated group; however differences between the two educational groups are only marginally significant.

Although highly educated women experienced a greater decrease in the number of leisure intervals, the smaller increase in leisure with respect to low educated women resulted in lower increases in the average duration of leisure intervals for highly educated women. Thus, highly educated women have experienced a higher fragmentation in leisure than low educated women. While highly educated women experienced a decrease in the number of leisure intervals of 0.35 intervals, low educated women experienced a decrease of just 0.26 intervals (this difference being statistically significant at the $99 \%$ level). However, the average duration of leisure intervals increased for low educated women over this period by 26 minutes per day, versus just a 15 minutes per day increase for highly educated women (the difference is statistically significant at the $99 \%$ level). Using a normalized measure of the average duration of leisure yields the same conclusion.

\section{Working Women}


Female labor force participation has substantially increased over this period. To the extent that increases in working hours are correlated to educational status, omitting employment status in our analysis may lead to a bias in our estimators. Panel $\mathrm{C}$ in Table 2 shows results for working women. The 1965-2003 increase in leisure time for working women with some high school and high school graduates is statistically significant, and accounts for almost seven hours per week, while the increase for the college educated group is much smaller, five hours per week. Column (4) shows that the two-hour difference in the leisure quantity trends between educational groups is statistically significant at the $99 \%$ level. Results on the quality of leisure for working women across educational groups are however mixed. Highly educated working women did not experience a statistically significant decrease in the percentage of pure leisure, although low educated working women experienced a decline of seven and a half percentage points, resulting in a decrease in the amount of pure leisure of one hour and 45 minutes $(22.51 * 7.70)$ (between 1965 and 1985 average pure leisure was 22 hours and 30 minutes for low educated working women).

Similarly to the results for all women, the probability of highly educated working women spending leisure time with the spouse increased to a much greater extent than that for low educated working women between 1965 and 2003 (10 and a half percentage points, and four percentage points, respectively). However, highly educated working women are less likely to be spending leisure time with other adults (three and a half percentage points, and one percentage point, respectively). Working women is the only group for which the number of leisure intervals increased over the period. However, highly educated working women experienced a smaller increase in the number of leisure intervals (0.32 versus 0.15 additional leisure intervals for low and highly educated working women, respectively). Similarly to women however, the increase in the average duration of leisure intervals was much higher for low educated working women (an increase of 21 minutes per day for low educated working women versus an increase of 14 minutes per day for highly educated women, significant at the $99 \%$ level).

\section{The Role of Television}

Time spent watching television has been one of the most important contributors to the increase in leisure during this period for both low and highly educated individuals and represents the highest proportion of total leisure time (44\% of leisure time for highly educated individuals, and $52 \%$ of leisure time for low educated individuals). To the extent that watching television can be considered low quality leisure, the fact that the time devoted to this activity has increased slightly 
more for low educated individuals over this period may explain why the quality of leisure declined more for low than for highly educated adults. ${ }^{18}$

To test this alternative explanation we undertake the analysis developed in the previous section omitting the time spent watching television. Table 3 shows that taking out 'TV watching' from the analysis results in a relatively flat pattern of leisure over this period for men, and a significant decrease of leisure for women. However, the apparent decline in leisure without television time is significantly higher for highly educated individuals. Thus, although the increase in the time spent watching TV seems responsible for the increases in leisure over this period, low educated individuals continue to experience a more favorable trend in leisure terms than highly educated individuals even after taking out the time spent watching television, so that increases in the time watching television cannot explain the differential trend in the quantity of leisure between educational groups.

Increases in the time watching television cannot entirely explain the differential trend in leisure in terms of quality either. The decline in leisure quality for all educational groups over this period continues to hold for the most part even after taking out the time spent watching television. Interestingly, the time spent with the spouse increases for highly educated men when the time spent watching television is excluded from the analysis, whereas low educated men and women decrease leisure with spouse to a greater extent after excluding television from the analysis. However the time spent watching TV can only account for the differential trend between the two educational groups in leisure with adults for men, but not for the variation in leisure quality between educational groups for women. Other leisure activities such as 'At Home Leisure' and 'Read/Listen', which also represent a significant fraction of the total amount of leisure time, similarly fail to explain the differential trend in leisure quality across educational groups.

\section{CONCLUSION}

\footnotetext{
${ }^{18} \mathrm{TV}$ watching seems to be low quality leisure. The literature reports that TV watching is a more passive or one-way communication medium (see Kubey and Csikszentmihalyi 1990), and evidence based on diary-affect data and general satisfaction surveys suggests that TV watching is not as enjoyable as other leisure activities. Consistent with what we see in Appendix B, TV watching ranks low in the level of instant enjoyment with respect to other leisure activities (Kahneman et al. 2004; Robinson and Godbey 1997). There is also substantial evidence showing that TV watching is negatively linked with life satisfaction in general (Espe and Seiwert 1987; Frey and Stutzer 2007; Kasser 2002; Morgan 1984; Putnam 1995;2000; Shrum, Borroughs and Rindfleisch 2003; Tankard and Harris 1990). Authors calculations show that TV watching is indeed less often enjoyed with other adults (61\% of the time as opposed to $65 \%$ for the rest of leisure activities) and it is also a more fragmented type of leisure.
} 
This paper moves beyond previous research, which has mostly focused on the total amount of time devoted to leisure, and begins to provide a more comprehensive view of how leisure inequality across educational groups has evolved over the period 1965 to 2003 in the US. We use the richness of the diary information in the American Heritage Time Use Study (AHTUS) to construct several indicators of the quality of leisure time, which are 'pure leisure', 'co-present leisure', and 'leisure fragmentation'. Consistent with previous studies, we find general increases in leisure time across educational groups between 1965 and 2003, especially for low educated individuals. However, although the quality of leisure has decreased over the period, this decline has been greatest for low educated adults. A possible explanation of the unequal distribution of leisure quantity and quality may be a greater decrease in the relative price of quality leisure for highly educated individuals than for low educated individuals over this period. We may speculate that this enables highly educated individuals to time their leisure so as to make it less fragmented, and to coordinate it with others' leisure, even if in exchange for a lower quantity of leisure. There is evidence that highly educated individuals use their earning power to work at more desirable times (despite working longer hours) than low educated individuals (see Hamermesh 1999, 2002). We leave a more thorough investigation of these important questions for further research.

\section{REFERENCES}

Aguiar, M. and E. Hurst. 2007. "Measuring Trends in Leisure: The Allocation of Time Over Five Decades." Quarterly Journal of Economics 122:969-1006.

Attanasio, O. and S. Davis. 1996. "Relative Wage Movements and the Distribution of Consumption,” Journal of Political Economy 104:1227-1262.

Autor, D. and L. Katz. 1999. "Changes in the Wage Structure and Earnings Inequality." in Handbook of Labor Economics, Volume 3A, edited by O. Ashenfelter and D. Card, NorthHolland.

Berkman, L.F. and T.A. Glass. 2000. "Social Integration, Social Networks, Social Support, and Health." in Social Epidemiology, edited by L.F. Berkman and I. Kawachi, New York: Oxford).

Berkman, L.F., M. Melchior, J.F. Chastang, I. Niedhammer, A. Leclerc and M. Goldber. 2004. "Social Integration and Mortality: A Prospective Study of French Employees of Electricity of France-Gas of France.” American Journal of Epidemiology 159:167-174. 
Bittman, M. and J. Wajcman. 2000. "The Rush Hour: The Character of Leisure Time and Gender Equity." Social Forces 79:165-189.

Biddle, J. and D. Hamermesh. 1990. "Sleep and the Allocation of Time." Journal of Political Economy 98:922-943.

Blossfeld, H. and A. Timm. 2003. "Who Marries Whom? Educational Systems as Marriage Markets in Modern Societies." European Studies of Population, Vol. 12. Springer.

Burda, M., D. Hamermesh and P. Weil. 2008. "The Distribution of Total Work in the EU and US," in Working Hours and Job Sharing in the EU and USA: Are Europeans Lazy? Or Americans Crazy?, edited by T. Boeri, M. Burdan and F. Kramarz, Oxford University Press.

Costa, D.L. 2000. “From Mill Town to Board Room: The Rise of Women's Paid Labor.” Journal of Economic Perspectives 14:101-122.

Csikszentmihalyi, M. 1990. Flow: The Psychology of Optimal Experience. New York: Harper Collins

Eng, P.M., E.B. Rimm, G. Fitzmaurice and I. Kawachi. 2002. "Social Ties and Changes in Social Ties in Relation to Subsequent Total and Cause-specific Mortality and Coronary Disease Incidence in Men.” American Journal of Epidemiology 155:700-709.

Espe, H. and M. Seiwert. 1987 "Television Viewing Types, General Life Satisfaction, and Viewing Amount: An Empirical Study in West Germany." European Journal of Comunication 13:95-110.

Fisher, K., M. Egerton, J. Gershuny and J. Robinson. 2007. "Gender Convergence in the American Heritage Time Use Study (AHTUS).” Social Indicators Research 82:1-33.

Fisher, K., M. Egerton, N. Torres, A. Pollmann and J. Gershuny. 2006. "American Historical Time-use surveys (AHTUS) Codebook." http://www.timeuse.org/ahtus/documentation/docs/pdf/Codebook.pdf.

Frey, B. and A. Stutzer. 2007. "Does Watching TV Make Us Happy." Journal of Economic Psychology 28:283-313.

Gershuny, J. 2009a. "Veblen in Reverse: Evidence from the Multinational Time-Use Archive." Social Indicators Research 93:37-45.

2009b. "Activities, durations and the empirical estimation of utility." Sociology Working Papers, 2009-07, University of Oxford. 
Gershuny, J. and B. Halpin. 1996. "Time Use, Quality of Life and Process Benefits." in Pursuit of the Quality of Life, edited by A. Offer, Oxford: Clarendon Press).

Ghez, G., and G. S. Becker. 1975. The Allocation of Time and Goods over the Life Cycle. New York: Columbia University Press.

Gimenez-Nadal, J.I. and R. Ortega-Lapiedra. Forthcoming "Self-employment and Time Stress: the Effect of Leisure Quality." Applied Economics Letters, DOI: $10.1080 / 13504850903266791$.

Hallberg, D. 2003. "Synchronous Leisure: Jointness and Household Labour Supply." Labour Economics 10:185-203.

Hamermesh, D. 1999. “The Timing of Work over Time.” Economic Journal 109:37-66. 2002. "Timing, Togetherness and time windfalls." Journal of Population Economics 15:601-623.

Hamermesh, D. and J. Lee. 2007. "Stressed Out on Four Continents: Time Crunch or Yuppie Kvetch.” Review of Economics and Statistics 89:374-384.

Hamermesh, D., C.K. Myers and M.L. Pocock. 2008. "Cues for Timing and Coordination: Latitude, Letterman, and Longitude.” Journal of Labor Economics 26:223-246.

Hawrylyshyn, O. 1976. "The Value of Household Services: A Survey of Empirical Results." Review of Income and Wealth 22:101-132. 1977. "Toward a Definition of of Non-Market Activities." Review of Income and Wealth 23:79-96.

Helliwell, J.F. and R.D. Putnam. 2005. "The Social Context of Well-being." in The Science of Well-Being, chapter 17, edited by F. Huppert, N. Beylis and B. Keverne, Oxford University Press).

House, J.S., K.R. Landis and D. Umberson. 1988. "Social Relationships and Health," Science 241:540-545.

Jenkins, S.P. and L. Osberg. 2005. "Nobody to Play with? The implications of Leisure Coordination." in The Economics of Time Use, edited by D. Hamermesh and G Pfann, Elsevier.

Juster, T. and F. Stafford. 1985. Time, Goods, and Well-Being. Ann Arbor, MI: Institute for Social Research. 
Kahneman, D., A. Krueger, D. Schkade, N. Schwarz and A. Stone. 2004. "A Survey Method for Characterizing Daily Life Experience: The Day Reconstruction Method." Science 3: 17761780.

Kahneman, D. and A. Krueger. 2006. "Developments in the Measurement of Subjective WellBeing.” Journal of Economic Perspectives 20:3-24.

Kasser, T. 2002. The High Price of Materialism. Cambridge, MA: MIT Press.

Krueger, A. 2007. "Are We Having More Fun Yet? Categorizing and Evaluating Changes in Time Allocation." Brookings Papers on Economic Activity 2:193-217.

Krueger, D. and F. Perri. 2006. "Does Income Inequality Lead to Consumption Inequality? Evidence and Theory." Review of Economic Studies 73:163-193.

Kubey, R. and M. Csikszentmihalyi. 1990. Television and the Quality of Life: How Viewing Shapes Everyday Experience. Lawrence Erlbaum Associates.

Knabe, A., S. Rätzel, R. Schöb and J. Weimann. Forthcoming. "Dissatisfied with Life, but Having a good Day: Time-Use and Well-Being of the Unemployed" Economic Journal, DOI: 10.1111/j.1468-0297.2009.02347.x.

Lam, D. 1988. "Marriage Markets and Assortative Mating with Household Public Goods: Theoretical Results and Empirical Implications.” Journal of Human Resources 23:462-487.

Mattingly, M.J. and M.S. Bianchi. 2003. "Gender Differences in the Quantity and Quality of Free Time: The U.S. Experience.” Social Forces 81:999-1030.

Mers, J. and L. Osberg. 2006. "Keeping in Touch: The Benefit of Public Holidays.” IZA Working Paper No. 2089.

Morgan, M. 1984. "Heavy Television Viewing and Preceived Quality of Life." Journalism Quarterly 61:499-504.

Putnam, R. 1995. "Tuning-in, Tuning-out - the Strange Dissapearance of Social Capital in America." Journal of Consumer Research 23: 278-294.

2000. Bowling Alone: the Collapse and Revival of American Community. New York: Simon \& Schuster.

Robinson, J. and G. Godbey. 1997. Time for Life: the Surprising Ways Americans Use Their Time. University Park, PA: Pennsylvania State University Press, second edition.

Robinson, J. 1993. “As we like it.” American Demographics 15:44-48. 
Schor, J. 1993. The Overworked American: the Unexpected Decline of Leisure. New York: Basic Books, originally published 1992.

Shrum, L., J. Borroughs and A. Rindfleisch. 2003. "Does Television Promote Materialism? Cultivating Desire for the Good Life." Paper presented at the annual conference of the International Communication Association, San Diego.

Singh-Manoux, A. and M. Marmot. 2005. "Role of Socialization in Explaining Social Inequalities in Health." Social Science and Medicine 60:2129-2133.

Stiglitz, J., A. Sen and J.P. Fitoussi. 2009. Report by the Commission on the Measurement of Economic Performance and Social Progress.

Steptoe, A., J. Wardle and M. Marmot. 2005. "Positive Affect and Health-Related Neuroendocrine, Cardiovascular, and Inflammatory Processes." Proceedings of the National Academy of Sciences 102:6508-6512.

Stone, A. and S. Shiffman. 1994. "Ecological Momentary Assessment (EMA) in Behavioral Medicine." Annals of Behavioral Medicine 16:199-202.

Sullivan, O. 1996a. "Time Co-ordination, the Domestic Division of Labour and Affect Relations: Time-use and the Enjoyment of Activities Within Couples." Sociology 30:79- 100.

. 1996b. "The Enjoyment of Activities: do Couples Affect Each Others' Wellbeing?" Social Indicators Research 38:81-102.

Szalai, A. 1972. The Use of Time. The Hague and Paris: Mouton Press.

Tankard. J. and M. Harris. 1990. "A Discriminant-Analysis of Television Viewers and NonViewers" Journal of Broadcasting 24:399-409.

Veblen, T. (1953) The Theory of the Leisure Class (New York, Mentor Books).

Walker, K. and W. Gauger. 1973. "Time and its Dollar Value in Household Work." Family Economics Review Fall 1973:8-13.

Weiss, Y. 1996. "Synchronization of Work Schedules." International Economic Review 37: 157179. 
Table 1. Trends in the quantity and quality of leisure by education level ${ }^{\text {a,b }}$

\begin{tabular}{|c|c|c|c|c|c|c|c|}
\hline & & 1965 & 1975 & 1985 & 1993 & 2003 & Diff. $1965-T_{i}^{\mathrm{c}}$ \\
\hline & & $(1)$ & $(2)$ & $(3)$ & $(4)$ & $(5)$ & $(6)$ \\
\hline \multicolumn{8}{|l|}{ Panel A: Men } \\
\hline \multirow[t]{3}{*}{ Leisure time } & All individuals & $\begin{array}{l}28.28 \\
(0.71)\end{array}$ & $\begin{array}{l}27.09 \\
(0.58)\end{array}$ & $\begin{array}{l}31.56 \\
(0.71)\end{array}$ & $\begin{array}{l}35.18 \\
(0.52)\end{array}$ & $\begin{array}{l}33.53 \\
(0.33)\end{array}$ & 5.26 \\
\hline & Low educated & $\begin{array}{l}29.29 \\
(0.87)\end{array}$ & $\begin{array}{l}27.9 \\
(0.83)\end{array}$ & $\begin{array}{l}32.48 \\
(0.97)\end{array}$ & $\begin{array}{l}36.18 \\
(0.85)\end{array}$ & $\begin{array}{l}35.72 \\
(0.57)\end{array}$ & 6.43 \\
\hline & Highly educated & $\begin{array}{l}25.94 \\
(1.20) \\
\end{array}$ & $\begin{array}{l}26.01 \\
(0.75) \\
\end{array}$ & $\begin{array}{l}30.5 \\
(1.05) \\
\end{array}$ & $\begin{array}{l}34.50 \\
(0.65) \\
\end{array}$ & $\begin{array}{l}32.13 \\
(0.39) \\
\end{array}$ & 6.19 \\
\hline \multirow[t]{3}{*}{ Percentage pure leisure } & All individuals & $\begin{array}{l}89.38 \\
(0.86)\end{array}$ & $\begin{array}{l}84.53 \\
(0.80)\end{array}$ & $\begin{array}{l}84.38 \\
(0.98)\end{array}$ & $\begin{array}{l}- \\
-\end{array}$ & $\begin{array}{l}- \\
-\end{array}$ & -5.00 \\
\hline & Low educated & $\begin{array}{l}89.36 \\
(1.03)\end{array}$ & $\begin{array}{l}85.66 \\
(1.08)\end{array}$ & $\begin{array}{l}82.92 \\
(1.43)\end{array}$ & - & - & -6.43 \\
\hline & Highly educated & $\begin{array}{l}89.44 \\
(1.55)\end{array}$ & $\begin{array}{l}83.02 \\
(1.19)\end{array}$ & $\begin{array}{l}86.04 \\
(1.34)\end{array}$ & - & - & -3.40 \\
\hline \multirow[t]{3}{*}{ Percentage leisure with spouse $^{\mathrm{d}}$} & All individuals & $\begin{array}{l}56.9 \\
(1.36)\end{array}$ & $\begin{array}{l}59.92 \\
(1.26)\end{array}$ & - & - & $\begin{array}{l}53.02 \\
(0.67)\end{array}$ & -3.88 \\
\hline & Low educated & $\begin{array}{l}59.16 \\
(1.61)\end{array}$ & $\begin{array}{l}60.19 \\
(1.67)\end{array}$ & - & - & $\begin{array}{l}54.18 \\
(1.12)\end{array}$ & -4.98 \\
\hline & Highly educated & $\begin{array}{l}51.7 \\
(2.52)\end{array}$ & $\begin{array}{l}59.52 \\
(1.89)\end{array}$ & - & - & $\begin{array}{l}52.31 \\
(0.84)\end{array}$ & 0.61 \\
\hline \multirow[t]{3}{*}{ Percentage leisure with adults } & All individuals & $\begin{array}{l}72.81 \\
(1.16)\end{array}$ & $\begin{array}{l}69.81 \\
(1.07)\end{array}$ & - & - & $\begin{array}{l}59.7 \\
(0.59)\end{array}$ & -13.11 \\
\hline & Low educated & $\begin{array}{l}74.41 \\
(1.36)\end{array}$ & $\begin{array}{l}71.29 \\
(1.36)\end{array}$ & - & - & $\begin{array}{l}61.23 \\
(0.95)\end{array}$ & -13.18 \\
\hline & Highly educated & $\begin{array}{l}69.12 \\
(2.18)\end{array}$ & $\begin{array}{l}67.82 \\
(1.72)\end{array}$ & - & - & $\begin{array}{l}58.72 \\
(0.74)\end{array}$ & -10.39 \\
\hline \multirow[t]{3}{*}{ Number of leisure intervals } & All individuals & $\begin{array}{l}2.98 \\
(0.06)\end{array}$ & $\begin{array}{l}2.68 \\
(0.04)\end{array}$ & $\begin{array}{l}3.28 \\
(0.07)\end{array}$ & $\begin{array}{l}2.47 \\
(0.03)\end{array}$ & $\begin{array}{l}2.99 \\
(0.02)\end{array}$ & 0.01 \\
\hline & Low educated & $\begin{array}{l}2.95 \\
(0.07)\end{array}$ & $\begin{array}{l}2.61 \\
(0.06)\end{array}$ & $\begin{array}{l}3.21 \\
(0.09)\end{array}$ & $\begin{array}{l}2.41 \\
(0.05)\end{array}$ & $\begin{array}{l}2.98 \\
(0.04)\end{array}$ & 0.03 \\
\hline & Highly educated & $\begin{array}{l}3.04 \\
(0.11)\end{array}$ & $\begin{array}{l}2.78 \\
(0.07)\end{array}$ & $\begin{array}{l}3.35 \\
(0.10)\end{array}$ & $\begin{array}{l}2.50 \\
(0.04)\end{array}$ & $\begin{array}{l}3.00 \\
(0.03)\end{array}$ & -0.05 \\
\hline \multirow{3}{*}{ Average duration of leisure intervals } & All individuals & $\begin{array}{l}87.13 \\
(2.20)\end{array}$ & $\begin{array}{l}94.41 \\
(2.00)\end{array}$ & $\begin{array}{l}90.10 \\
(2.21)\end{array}$ & $\begin{array}{l}127.92 \\
(1.84)\end{array}$ & $\begin{array}{l}105.82 \\
(1.21)\end{array}$ & 18.69 \\
\hline & Low educated & $\begin{array}{l}92.07 \\
(2.68)\end{array}$ & $\begin{array}{l}96.56 \\
(2.72)\end{array}$ & $\begin{array}{l}95.70 \\
(3.23)\end{array}$ & $\begin{array}{l}133.62 \\
(3.17)\end{array}$ & $\begin{array}{l}113.93 \\
(2.13)\end{array}$ & 21.86 \\
\hline & Highly educated & $\begin{array}{l}75.73 \\
(3.73)\end{array}$ & $\begin{array}{l}91.54 \\
(2.95)\end{array}$ & $\begin{array}{l}83.73 \\
(2.95)\end{array}$ & $\begin{array}{l}124.05 \\
(2.21)\end{array}$ & $\begin{array}{l}100.63 \\
(1.45)\end{array}$ & 24.90 \\
\hline \multicolumn{8}{|l|}{ Panel B: Women } \\
\hline \multirow[t]{3}{*}{ Leisure time } & All individuals & $\begin{array}{l}27.16 \\
(0.54)\end{array}$ & $\begin{array}{l}31.52 \\
(0.46)\end{array}$ & $\begin{array}{l}31.00 \\
(0.60)\end{array}$ & $\begin{array}{l}32.79 \\
(0.44)\end{array}$ & $\begin{array}{l}30.72 \\
(0.27)\end{array}$ & 3.56 \\
\hline & Low educated & $\begin{array}{l}27.35 \\
(0.63)\end{array}$ & $\begin{array}{l}33.05 \\
(0.56)\end{array}$ & $\begin{array}{l}32.36 \\
(0.80)\end{array}$ & $\begin{array}{l}35.06 \\
(0.70)\end{array}$ & $\begin{array}{l}33.02 \\
(0.46)\end{array}$ & 5.67 \\
\hline & Highly educated & $\begin{array}{l}26.55 \\
(1.05) \\
\end{array}$ & $\begin{array}{l}27.54 \\
(0.79) \\
\end{array}$ & $\begin{array}{l}29.15 \\
(0.90) \\
\end{array}$ & $\begin{array}{l}31.15 \\
(0.55) \\
\end{array}$ & $\begin{array}{l}29.31 \\
(0.32) \\
\end{array}$ & 2.77 \\
\hline \multirow[t]{3}{*}{ Percentage pure leisure } & All individuals & $\begin{array}{l}87.74 \\
(0.79)\end{array}$ & $\begin{array}{l}85.61 \\
(0.60)\end{array}$ & $\begin{array}{l}82.05 \\
(0.93)\end{array}$ & $\begin{array}{l}- \\
-\end{array}$ & $\begin{array}{l}- \\
-\end{array}$ & -5.69 \\
\hline & Low educated & $\begin{array}{l}87.34 \\
(0.92)\end{array}$ & $\begin{array}{l}85.73 \\
(0.70)\end{array}$ & $\begin{array}{l}80.73 \\
(1.28)\end{array}$ & - & - & -6.61 \\
\hline & Highly educated & $\begin{array}{l}89.01 \\
(1.50) \\
\end{array}$ & $\begin{array}{l}85.31 \\
(1.19) \\
\end{array}$ & $\begin{array}{l}83.85 \\
(1.33)\end{array}$ & - & $\begin{array}{l}- \\
- \\
\end{array}$ & -5.15 \\
\hline \multirow[t]{3}{*}{ Percentage leisure with spouse $^{\mathrm{d}}$} & All individuals & $\begin{array}{l}44.52 \\
(1.27)\end{array}$ & $\begin{array}{l}45.24 \\
(1.05)\end{array}$ & $\begin{array}{l}- \\
-\end{array}$ & - & $\begin{array}{l}49.55 \\
(0.62)\end{array}$ & 5.03 \\
\hline & Low educated & $\begin{array}{l}45.77 \\
(1.44)\end{array}$ & $\begin{array}{l}44.36 \\
(1.21)\end{array}$ & - & - & $\begin{array}{l}49.13 \\
(1.04)\end{array}$ & 3.36 \\
\hline & Highly educated & $\begin{array}{l}40.54 \\
(2.62) \\
\end{array}$ & $\begin{array}{l}47.57 \\
(2.09) \\
\end{array}$ & - & - & $\begin{array}{r}49.80 \\
(0.78) \\
\end{array}$ & 9.26 \\
\hline \multirow[t]{3}{*}{ Percentage leisure with adults } & All individuals & $\begin{array}{l}68.10 \\
(1.09)\end{array}$ & $\begin{array}{l}67.72 \\
(0.86)\end{array}$ & - & - & $\begin{array}{l}61.22 \\
(0.51)\end{array}$ & -6.88 \\
\hline & Low educated & $\begin{array}{l}68.80 \\
(1.25)\end{array}$ & $\begin{array}{l}68.46 \\
(1.00)\end{array}$ & - & - & $\begin{array}{l}62.68 \\
(0.84)\end{array}$ & -6.12 \\
\hline & Highly educated & $\begin{array}{l}65.92 \\
(2.24)\end{array}$ & $\begin{array}{l}65.80 \\
(1.68)\end{array}$ & - & - & $\begin{array}{l}60.33 \\
(0.65)\end{array}$ & -5.59 \\
\hline
\end{tabular}




\begin{tabular}{|c|c|c|c|c|c|c|c|}
\hline \multirow[t]{3}{*}{ Number of leisure intervals } & All individuals & $\begin{array}{l}3.52 \\
(0.07)\end{array}$ & $\begin{array}{l}3.55 \\
(0.05)\end{array}$ & $\begin{array}{l}3.75 \\
(0.07)\end{array}$ & $\begin{array}{l}2.58 \\
(0.03)\end{array}$ & $\begin{array}{l}3.25 \\
(0.02)\end{array}$ & -0.26 \\
\hline & Low educated & $\begin{array}{l}3.48 \\
(0.07)\end{array}$ & $\begin{array}{l}3.62 \\
(0.06)\end{array}$ & $\begin{array}{l}3.61 \\
(0.09)\end{array}$ & $\begin{array}{l}2.63 \\
(0.05)\end{array}$ & $\begin{array}{l}3.22 \\
(0.04)\end{array}$ & -0.27 \\
\hline & Highly educated & $\begin{array}{l}3.61 \\
(0.14) \\
\end{array}$ & $\begin{array}{l}3.37 \\
(0.08) \\
\end{array}$ & $\begin{array}{l}3.95 \\
(0.11) \\
\end{array}$ & $\begin{array}{l}2.55 \\
(0.04) \\
\end{array}$ & $\begin{array}{l}3.27 \\
(0.03) \\
\end{array}$ & -0.34 \\
\hline \multirow{3}{*}{ Average duration of leisure intervals } & All individuals & $\begin{array}{l}71.67 \\
(1.45)\end{array}$ & $\begin{array}{l}86.59 \\
(1.45)\end{array}$ & $\begin{array}{l}78.17 \\
(1.75)\end{array}$ & $\begin{array}{l}116.39 \\
(1.66)\end{array}$ & $\begin{array}{l}90.04 \\
(0.91)\end{array}$ & 18.37 \\
\hline & Low educated & $\begin{array}{l}72.8 \\
(1.69)\end{array}$ & $\begin{array}{l}90.78 \\
(1.82)\end{array}$ & $\begin{array}{l}84.04 \\
(2.34)\end{array}$ & $\begin{array}{l}124.28 \\
(2.75)\end{array}$ & $\begin{array}{l}99.38 \\
(1.66)\end{array}$ & 26.58 \\
\hline & Highly educated & $\begin{array}{l}68.09 \\
(2.83)\end{array}$ & $\begin{array}{l}75.68 \\
(2.10)\end{array}$ & $\begin{array}{l}70.14 \\
(2.55)\end{array}$ & $\begin{array}{l}110.66 \\
(2.03)\end{array}$ & $\begin{array}{l}84.32 \\
(1.04)\end{array}$ & 16.24 \\
\hline
\end{tabular}

Note: Values in parentheses in columns 1 to 5 are standard deviations.

Source: The sample consists of respondents in the AHTUS (1965-2003) who are not retired, are not students, and are aged 21-65.

a Leisure time measures the hours per week devoted to leisure activities; pure leisure measures the amount of leisure that is reported as primary activity whose secondary activity is also leisure or with no secondary activity; leisure with spouse measures the amount of leisure that is done with a co-present partner; leisure with adults measures the amount of leisure that is done with a co-present adult; number of leisure intervals measures the number of leisure intervals in the diary; and average duration of leisure intervals measures the mean duration of leisure intervals in minutes per day.

b Low-educated individuals are defined as those with 12 years of education or less; highly educated individuals are defined as having more than 12 years of education.

c Ti is 2003 for all the dependent variables, with the exception of the percentage of pure leisure, for which $\mathrm{Ti}$ is 1985 .

$\mathrm{d}$ We restrict the sample to those individuals with a partner. 
Table 2: Trends in leisure by educational status ${ }^{\mathrm{a}, \mathrm{b}}$

\begin{tabular}{|c|c|c|c|c|}
\hline & $(1)$ & $(2)$ & (3) & $(4)$ \\
\hline Panel A: Men & $\begin{array}{c}\text { Low Education } \\
\beta^{\mathrm{e}<=12} \mathrm{Ti}\end{array}$ & $\begin{array}{c}\text { High Education } \\
\beta^{\mathrm{e}>12}{ }_{\mathrm{Ti}}\end{array}$ & \multicolumn{2}{|c|}{$\begin{array}{c}\text { Diff. p-value } \\
(1)-(2)^{(c)}\end{array}$} \\
\hline Leisure time & $\begin{array}{c}5.26^{* * * *} \\
(0.30)\end{array}$ & $\begin{array}{c}4.44 * * * \\
(0.24)\end{array}$ & 0.82 & $(0.03)$ \\
\hline Percentage pure leisure & $\begin{array}{c}-6.33 * * * \\
(0.14)\end{array}$ & $\begin{array}{c}-3.54 * * * \\
(0.16)\end{array}$ & -2.79 & $(<0.01)$ \\
\hline Percentage leisure with spouse ${ }^{(\mathrm{d})}$ & $\begin{array}{c}-5.97 * * * \\
(0.18)\end{array}$ & $\begin{array}{c}0.24 \\
(0.34)\end{array}$ & -6.21 & $(<0.01)$ \\
\hline Percentage leisure with adults & $\begin{array}{c}-10.54 * * * \\
(0.72)\end{array}$ & $\begin{array}{c}-6.81 * * * \\
(0.49)\end{array}$ & -3.72 & $(<0.01)$ \\
\hline Number of leisure intervals & $\begin{array}{c}0.00 \\
(0.01)\end{array}$ & $\begin{array}{c}-0.11 * * * \\
(0.02)\end{array}$ & 0.11 & $(<0.01)$ \\
\hline Average duration of leisure intervals ${ }^{(\mathrm{e})}$ & $\begin{array}{c}18.19 * * * \\
(1.04)\end{array}$ & $\begin{array}{c}20.10^{* * * *} \\
(0.47)\end{array}$ & -1.91 & $(0.08)$ \\
\hline Panel B: Women & $\begin{array}{c}\text { Low Education } \\
\beta^{\mathrm{e}<=12}{ }_{\mathrm{Ti}} \\
\end{array}$ & $\begin{array}{c}\text { High Education } \\
\beta^{\mathrm{e}>12} \mathrm{Ti} \\
\end{array}$ & \multicolumn{2}{|c|}{$\begin{array}{c}\text { Diff. p-value } \\
(1)-(2)^{(c)}\end{array}$} \\
\hline Leisure time & $\begin{array}{c}5.47 * * * \\
(0.12)\end{array}$ & $\begin{array}{c}2.09^{* * *} \\
(0.05)\end{array}$ & 3.38 & $(<0.01)$ \\
\hline Percentage pure leisure & $\begin{array}{c}-6.80 * * * \\
(0.38)\end{array}$ & $\begin{array}{c}-4.35^{* * * *} \\
(0.29)\end{array}$ & -2.45 & $(<0.01)$ \\
\hline Percentage leisure with spouse ${ }^{(\mathrm{d})}$ & $\begin{array}{c}2.74 * * \\
(0.41)\end{array}$ & $\begin{array}{c}8.11 * * * \\
(0.11)\end{array}$ & -5.37 & $(<0.01)$ \\
\hline Percentage leisure with adults & $\begin{array}{c}-4.69 * * * \\
(0.06)\end{array}$ & $\begin{array}{c}-4.89 * * * \\
(0.08)\end{array}$ & 0.19 & $(0.05)$ \\
\hline Number of leisure intervals & $\begin{array}{c}-0.26 * * * \\
(0.02)\end{array}$ & $\begin{array}{c}-0.35 * * * \\
(0.00)\end{array}$ & 0.09 & $(<0.01)$ \\
\hline Average duration of leisure intervals ${ }^{(e)}$ & $\begin{array}{c}25.64 * * * \\
(0.15)\end{array}$ & $\begin{array}{c}14.53 * * * \\
(0.10)\end{array}$ & 11.11 & $(<0.01)$ \\
\hline Panel C: Working Women & $\begin{array}{c}\text { Low Education } \\
\beta^{\mathrm{e}<=12}{ }_{\mathrm{Ti}}\end{array}$ & $\begin{array}{c}\text { High Education } \\
\beta^{\mathrm{e}>12} \mathrm{Ti} \\
\end{array}$ & Diff. & \\
\hline Leisure time & $\begin{array}{c}6.98 * * * \\
(0.11)\end{array}$ & $\begin{array}{c}.04 * * * \\
(0.02)\end{array}$ & 1.94 & $(<0.01)$ \\
\hline Percentage pure leisure & $\begin{array}{c}-7.70 * * * \\
(0.33)\end{array}$ & $\begin{array}{l}-0.97 \\
(0.83)\end{array}$ & -6.73 & $(<0.01)$ \\
\hline Percentage leisure with spouse ${ }^{(\mathrm{d})}$ & $\begin{array}{c}4.16^{* * * *} \\
(0.17)\end{array}$ & $\begin{array}{c}10.58 * * * \\
(0.41)\end{array}$ & -6.43 & $(<0.01)$ \\
\hline Percentage leisure with adults & $\begin{array}{c}-1.08 * * \\
(0.14)\end{array}$ & $\begin{array}{c}-3.41 * * \\
(0.36)\end{array}$ & 2.33 & $(<0.01)$ \\
\hline Number of leisure intervals & $\begin{array}{c}0.32 * * * \\
(0.01)\end{array}$ & $\begin{array}{c}0.15^{* * *} * \\
(0.00)\end{array}$ & 0.17 & $(<0.01)$ \\
\hline Average duration of leisure intervals ${ }^{(e)}$ & $\begin{array}{c}20.87 * * * \\
(0.33)\end{array}$ & $\begin{array}{c}13.60 * * * \\
(0.16)\end{array}$ & 7.27 & $(<0.01)$ \\
\hline
\end{tabular}

Note: Standard errors in parentheses in Columns (1) and (2), p-value of the difference between the coefficients in parentheses in Column (4).

Source: Sample consists of respondents in the AHTUS (1965-2003), who are not retired, are not students and are aged 21-65.

${ }^{\text {a }}$ Low educated individuals are defined as with 12 years of education or less; Highly educated individuals are defined as having more than 12 years of education.

${ }^{\mathrm{b}}$ We estimate the following equation by Ordinary Least Squares: $\mathrm{Y}_{\mathrm{it}}^{\mathrm{e}}=\alpha^{\mathrm{e}}+\beta_{\mathrm{it}}^{\mathrm{e}} D_{i t}+\gamma^{\mathrm{e}} \mathrm{x}_{i t}^{\mathrm{e}}+\xi_{\mathrm{it}}^{\mathrm{e}}$ where $Y_{i t}$ is the time dependent variable, $\mathbf{X}_{\mathbf{i t}}$ is a vector of controls including respondent's age and the presence of children in the household, and $\mathbf{D}_{\mathbf{i t}}$ is a vector of year dummies (Ref.: 1965). Day (Ref.: Friday) are also included in the regressions.

${ }^{\mathrm{c}} \mathrm{T}_{\mathrm{i}}$ is 2003 for all the dependent variables, with the exception of the Percentage of Pure Leisure where $\mathrm{T}_{\mathrm{i}}$ is 1985.

${ }^{\mathrm{d}}$ We restrict the sample to those individuals with a partner.

${ }^{\mathrm{e}}$ Average duration of leisure intervals is measures in minutes per day

$* p<.10 * * p<.05 * * * p<.01$ 
Table 3- Trends in leisure by educational status, without TV watching ${ }^{\text {a,b }}$

\begin{tabular}{|c|c|c|c|c|}
\hline & $(1)$ & (2) & (3) & $(4)$ \\
\hline Panel A: Men & $\begin{array}{c}\text { Low Education } \\
\beta^{\mathrm{e}<=12} \mathrm{Ti}\end{array}$ & $\begin{array}{c}\text { High Education } \\
\beta^{\mathrm{e}>12} \mathrm{Ti}\end{array}$ & \multicolumn{2}{|c|}{$\begin{array}{l}\text { Diff. p-value } \\
(1)-(2)^{(\mathrm{c})}\end{array}$} \\
\hline Leisure time & -0.13 & $-0.49 * * *$ & 0.36 & $(<0.01)$ \\
\hline Percentage pure leisure & $\begin{array}{c}(0.06) \\
-6.43 * *\end{array}$ & $\begin{array}{c}(0.08) \\
-5.48 * * *\end{array}$ & -0.96 & $(0.36)$ \\
\hline & $(0.80)$ & $(0.52)$ & & \\
\hline Percentage leisure with spouse ${ }^{(\mathrm{d})}$ & $-3.99 * * *$ & $1.86^{* *}$ & -5.84 & $(<0.01)$ \\
\hline Percentage leisure with adults & $\begin{array}{c}(0.26) \\
-3.02 * *\end{array}$ & $\begin{array}{c}(0.36) \\
-4.45^{* * *}\end{array}$ & 1.43 & $(<0.01)$ \\
\hline Number of leisure intervals & $\begin{array}{c}(0.47) \\
-0.22 * * *\end{array}$ & $\begin{array}{c}(0.28) \\
-0.31 * * *\end{array}$ & 0.09 & $(<0.01)$ \\
\hline Average duration of leisure intervals ${ }^{(\mathrm{e})}$ & $\begin{array}{c}(0.00) \\
24.61 * * * \\
(0.88)\end{array}$ & $\begin{array}{c}(0.01) \\
25.89 * * * \\
(0.58)\end{array}$ & 1.28 & $(0.21)$ \\
\hline Panel B: Women & $\begin{array}{c}\text { Low Education } \\
\beta^{\mathrm{e}<=12} \mathrm{Ti}\end{array}$ & $\begin{array}{c}\text { High Education } \\
\beta^{\text {e>12 }}{ }^{\mathrm{Ti}}\end{array}$ & Diff & $\begin{array}{l}\text { p-value } \\
\text { (c) }^{(1)}\end{array}$ \\
\hline Leisure time & $\begin{array}{c}-1.81 * * * \\
(0.09)\end{array}$ & $\begin{array}{c}-3.77 * * * \\
(0.03)\end{array}$ & 1.96 & $(<0.01)$ \\
\hline Percentage pure leisure & $\begin{array}{c}-8.70 * * * \\
(0.60)\end{array}$ & $\begin{array}{c}-3.64 * * * \\
(0.19)\end{array}$ & -5.06 & $(<0.01)$ \\
\hline Percentage leisure with spouse ${ }^{(\mathrm{d})}$ & $\begin{array}{c}-1.35 * * * \\
(0.07)\end{array}$ & $\begin{array}{c}4.12 * * * \\
(0.13)\end{array}$ & -5.46 & $(<0.01)$ \\
\hline Percentage leisure with adults & $\begin{array}{c}-6.58 * * * \\
(0.28)\end{array}$ & $\begin{array}{c}-6.43 * * * \\
(0.09)\end{array}$ & -0.15 & $(0.58)$ \\
\hline Number of leisure intervals & $\begin{array}{c}-0.60 * * * \\
(0.02)\end{array}$ & $\begin{array}{c}-0.75^{* * * *} \\
(0.00)\end{array}$ & 0.14 & $(<0.01)$ \\
\hline Average duration of leisure intervals ${ }^{(\mathrm{e})}$ & $\begin{array}{c}36.02 * * * \\
(0.21)\end{array}$ & $\begin{array}{c}26.97 * * * \\
(0.18)\end{array}$ & 9.05 & $(<0.01)$ \\
\hline
\end{tabular}

Note: Standard errors in parentheses in Columns (1) and (2), p-value of the difference between the coefficients in parentheses in Column (4).

Source: Sample consists of respondents in the AHTUS (1965-2003), who are not retired, are not students and are aged 21-65.

${ }^{a}$ Low educated individuals are defined as with 12 years of education or less; Highly educated individuals are defined as having more than 12 years of education.

${ }^{\mathrm{b}}$ We estimate the following equation by Ordinary Least Squares: $Y_{\mathrm{it}}^{\mathrm{e}}=\alpha^{\mathrm{e}}+\beta_{\mathrm{it}}^{\mathrm{e}}{ }_{i t}+\gamma^{\mathrm{e}} \mathrm{x}_{i t}^{e}+\xi_{\mathrm{it}}^{\mathrm{e}}$ where $Y_{i t}$ is the time dependent variable, $\mathbf{X}_{\mathbf{i t}}$ is a vector of controls including respondent's age and the presence of children in the household, and $\mathbf{D}_{\mathbf{i t}}$ is a vector of year dummies (Ref.: 1965). Day (Ref.:Friday) are also included in the regressions.

${ }^{\mathrm{c}} \mathrm{T}_{\mathrm{i}}$ is 2003 for all the dependent variables, with the exception of the Percentage of Pure Leisure where $\mathrm{T}_{\mathrm{i}}$ is 1985.

${ }^{\mathrm{d}}$ We restrict the sample to those individuals with a partner.

${ }^{\mathrm{e}}$ Average duration of leisure intervals is measures in minutes per day

$* p<.10 * * p<.05 * * * p<.01$ 


\section{APPENDIX A: TECHNICAL INFORMATION}

\section{Sample Selection}

For the sake of comparison with previous studies, and to minimize the role of time allocation decisions, such as education and retirement, that have a strong inter-temporal component over the life cycle, we restrict the sample used throughout the analysis to non-retired/non-student individuals between the ages of 21 and 65 (inclusive); results should be interpreted as being "per working-age adult" (or per adult within the specified sub-sample, when relevant). This approach also avoids possible biases from the changing proportion of retired individuals in the general population over this long period.

Not including individuals out of the labor force may be particularly problematic if low educated individuals are more likely to be non-employed and thus have a higher amount of leisure. This is a problem that we share with previous studies that look at trends in the amount of leisure. The fact that we control for total leisure time in our analysis makes this issue less problematic for our indicators of leisure quality, though possible biases remain if low educated individuals are more likely to be retired and if leisure time during retirement differs in its quality from that during the active working years. We have conducted robustness checks including retired and non-retired individuals between 24-65 and 24-72 years old. Results do not change (available on request).

We also restrict the sample to include only individuals who have time diaries that add up to a complete day (1440 minutes) and whose diary is not "low quality", i.e., the diary has 90 minutes or less missing main activity time, it has seven or more episodes, and it records some time in at least three of four basic activities (sleep or rest, eat or drink, personal care, and travel), either as a primary or secondary activity. ${ }^{1}$ The excluded diaries represent $10 \%$ of the age $21-65$ sample, and results are robust to their inclusion.

We further limit the sample to married individuals or those individuals living with a partner wherever the dependent variable is the quality indicator percentage of leisure time with the spouse. This sample restriction is necessary because trends in marriage rates and the timing of marriage have changed over time, especially for highly educated individuals, and if marriage patterns alter behavior in daily routines, such as time together, they could in principle explain some patterns in the data.

\footnotetext{
${ }^{1}$ Some respondents providing child-care to multiple children, or to an infant, as well as some diarists performing adult care did not record travel and also missed a second or third basic activity. If these diaries from carers nonetheless included at least 10 episodes, then we counted these diaries as good diaries (as it may be possible the diarists ate while feeding the care recipient, for example, but did not record her or his own eating).
} 
Table A1- AHTUS description

\begin{tabular}{|c|c|c|c|}
\hline \multicolumn{4}{|c|}{ Study aims, target populations, and sample restrictions } \\
\hline Survey years & Organizing Aims and Considerations & Target Population & Sampling Restrictions \\
\hline 1965-1966 & $\begin{array}{l}\text { Aimed to be comparable with the } \\
\text { Multinational Comparative Time-Budget } \\
\text { project collected in } 12 \text { countries }\end{array}$ & $\begin{array}{l}\text { The national working age population (19-64) of } \\
\text { the USA (excluding families where all members } \\
\text { worked as farmers) }\end{array}$ & $\begin{array}{l}\text { Only people aged } 19 \text { to } 64 \text { (with a few older diarists), } \\
\text { and one person per household (Alaska, Hawaii, and } \\
\text { some smaller, rural states excluded) }\end{array}$ \\
\hline 1975-1976 & $\begin{array}{l}\text { Aimed to measure national accounts and } \\
\text { changes in time use over the year }\end{array}$ & The national adult population & $\begin{array}{l}\text { People aged } 18 \text { or older and one person plus spouse if } \\
\text { present per household }\end{array}$ \\
\hline 1985 & $\begin{array}{l}\text { Aimed to determine how people used their } \\
\text { time and to compare diaries collected by } \\
\text { post-out/post-back, phone, and face-to-face } \\
\text { interview }\end{array}$ & $\begin{array}{l}\text { The national population beyond secondary } \\
\text { school age not living in institutions }\end{array}$ & $\begin{array}{l}\text { People aged } 12 \text { or older living in private households } \\
\text { with phones (Alaska, Hawaii, and some smaller, rural } \\
\text { states excluded) }\end{array}$ \\
\hline 1992-1994 & Aimed to measure time use and exposure & $\begin{array}{l}\text { The national population living in private } \\
\text { residences }\end{array}$ & $\begin{array}{l}1 \text { person of any age living in sampled private } \\
\text { households with phones (Alaska and Hawaii } \\
\text { excluded) }\end{array}$ \\
\hline 2003 & $\begin{array}{l}\text { Aimed to follow a sub-sample of the CPS } \\
\text { for a } 9^{\text {th }} \text { wave to facilitate the study of } \\
\text { national accounts }\end{array}$ & $\begin{array}{l}\text { The national population not living in military } \\
\text { bases or institutions }\end{array}$ & 1 person aged 15 or older in the household \\
\hline \multicolumn{4}{|c|}{ Relevant points in time from the sample designs } \\
\hline Survey years & Fieldwork Period & Sampling of Days of the Week & When Activities Were Recorded \\
\hline $1965-1966$ & $\begin{array}{l}15 \text { November -15 December 1965; } \\
1 \text { January - } 18 \text { February 1966; } 7 \text { March - } 20 \\
\text { May, } 1966\end{array}$ & $\begin{array}{l}2 / 7 \text { ths of diaries were stamped for collection on } \\
\text { a weekend day; } 5 / 7 \text { ths were stamped for } \\
\text { collection on a weekday }\end{array}$ & $\begin{array}{l}\text { A two-stage tomorrow approach, diaries left behind } \\
\text { for completion on diary day }\end{array}$ \\
\hline 1975-1976 & $\begin{array}{l}\text { Wave 1: } 9 \text { October } 1975 \text { - } 22 \text { November } \\
\text { 1975; Wave 2: } 6 \text { February } 1976 \text { - } 28 \text { March } \\
\text { 1976; Wave 3: } 2 \text { May } 1976 \text { - } 19 \text { July } 1976 ; \\
\text { Wave 4: } 4 \text { September } 1976 \text { - } 26 \text { October } \\
\text { 1976 }\end{array}$ & $\begin{array}{l}\text { The study aimed to collect one diary on a } \\
\text { Sunday, one on a Saturday, and two on different } \\
\text { weekdays from each sample member. }\end{array}$ & Diaries covered the previous 24 hour day \\
\hline 1985 & Whole year of 1985 & Mail-out after phone calls. & $\begin{array}{l}\text { Diaries to be completed on a specified day in the } \\
\text { subsequent week }\end{array}$ \\
\hline 1992-1994 & September 1992 - October 1994 & $\begin{array}{l}\text { Phone calls were attempted on all days of the } \\
\text { week. }\end{array}$ & Diaries covered the previous 24 hour day \\
\hline 2003 & Whole year of 2003 & $\begin{array}{l}\text { Half of diaries were collected on weekday, half } \\
\text { on weekend days. }\end{array}$ & Diaries covered the previous 24 hour day \\
\hline \multicolumn{4}{|c|}{ Sample designs and response rates } \\
\hline Survey years & Sample Frame & How Sample Drawn & Response Rate \\
\hline 1965-1966 & $\begin{array}{l}\text { Jackson, Michigan and surrounding } \\
\text { townships, and a national sample }\end{array}$ & $\begin{array}{l}\text { Jackson - random selection; National multi- } \\
\text { stage clustered area sampling of clusters } \\
\text { containing around } 4 \text { addresses; one individual } \\
\text { per household }\end{array}$ & $82 \%$ in Jackson; $74 \%$ in the national sample \\
\hline 1975-1976 & Private households & $\begin{array}{l}\text { Stratified, clustered and probability selection } \\
\text { within strata. One individual was sampled per } \\
\text { household. Data was also collected from } \\
\text { spouses where present. }\end{array}$ & $\begin{array}{l}72 \% \text { in the first wave; } 44.9 \% \text { responded to all four } \\
\text { waves }\end{array}$ \\
\hline 1985 & $\begin{array}{l}\text { Adults } 18 \text { years or over, living in houses } \\
\text { with telephones in the contiguous United } \\
\text { States. }\end{array}$ & $\begin{array}{l}\text { Stratified and clustered, random-digit dialing, } \\
\text { with only private residences pursued for an } \\
\text { interview. Information on the household } \\
\text { collected by telephone. }\end{array}$ & $55.2 \%$ overall, $51 \%$ for mail back sample \\
\hline 1992-1994 & $\begin{array}{l}\text { Potential phone numbers within lists of } \\
\text { area codes }\end{array}$ & $\begin{array}{l}\text { Random-digit dialing, only private residences } \\
\text { pursued for interview. The person who would } \\
\text { next have a birthday completed the diary. }\end{array}$ & $63 \%$ \\
\hline 2003 & The CPS sample & $\begin{array}{l}\text { A random sub-sample of the CPS, with the } \\
\text { over-sampling of small states dropped but } \\
\text { families with children over-sampled. Half of the } \\
\text { diaries are collected on week days, the other } \\
\text { half on weekend days }\end{array}$ & $57.8 \%$ \\
\hline
\end{tabular}

Source: Fisher et al. [2006] 


\section{APPENDIX B: VALIDATING THE FOUR CLASSES OF INDICATORS}

In this Section we validate our leisure quality indicators using the 1985 element of the AHTUS, which collected an additional item of information not available elsewhere in the sequence of surveys: an activity enjoyment "rating" (on a 0-10 "dislike it"/ "like it" scale) attached to each event (see Robinson 1997). The 1985 AHTUS did not include however the "with whom?" diary information for each registered event. We use a similar diary dataset (though rating activities on a 1-5 "like it"/ "dislike it" scale, and collecting information on a fixed 30 minute grid, rather than the open intervals used in the US survey), from a national random sample of individuals living as members of heterosexual couples in the UK in 1986, which does include co-presence data (see Sullivan 1996a; 1996b).

We estimate the following equation on the event level datasets (i.e., case =diary event), weighting the cases by the duration of the event, using OLS and Ordered logit models:

$$
E_{i, j}=\beta_{1} I_{i, j}+\beta_{2} X_{i}+\beta_{3} A_{i, j}+\varepsilon_{i, j}
$$

where " $\mathrm{i}$ " is the individual (or a diary) and " $\mathrm{j}$ " is the episode in the diary characterized by a unique primary leisure activity. ${ }^{21}$ The dependent variable $E_{i, j}$ is the activity enjoyment "rating". The data has multiple events from the same diarist for the same diary days, and we therefore present the more conservative OLS model, the OLS model with robust standard errors and clustered by diarist, and the logit model. We select the same age range from the two samples (21-65).

The vector $\mathbf{I}_{\mathbf{i}, \mathbf{j}}$ contains four leisure-quality indicators as described in Section 3. The vector $\mathbf{X}_{\mathbf{i}}$ includes socio-economic variables of the individual, which include age, age squared, gender, an indicator variable for part time and full time work, an indicator variable that takes value one if there is a child under 5 at home, and another indicator variable that takes value one if there is a child between 5 and 18 years old living in the household. The vector $\mathbf{A}_{\mathbf{i}, \mathbf{j}}$ includes six dummy variables indicating the nature of the leisure activity being done. These are classified into "out of home leisure", "active sport and exercise", "read and listening to music", "watch television" (reference activity), "other leisure at home" and "writing".

Panels A and B in Table B1 show the associations between the leisure-quality indicators and the enjoyment scores in the US and the UK data, respectively. In all specifications, it emerges that these indicators are all associated with the activity enjoyment ratings in the expected way. The fragmentation effects, meanwhile, are hardly affected by the additional variables.

\footnotetext{
${ }^{21}$ The question these models are attempting to address is how well the leisure quality proxies explain the variation in enjoyment across leisure activities. Thus, we restrict our analysis to leisure activities, since including all the activities (work, leisure, sleep) would capture the proportion of explained variation in enjoyment across all activities, not the proportion across leisure activities, and some significant share of that explained variation would be accounted for by activity type variables rather than the proxies for leisure quality.
} 
Table B1 - Regressions on activity enjoyment $\operatorname{ratings}^{\mathrm{a}, \mathrm{b}}$

\begin{tabular}{|c|c|c|c|c|c|c|c|c|}
\hline \multirow[b]{2}{*}{ Rating } & \multicolumn{4}{|c|}{ The US } & \multicolumn{4}{|c|}{ The UK } \\
\hline & $(1)$ & $(2)$ & $(3)$ & $(4)$ & $(5)$ & $(6)$ & $(7)$ & $(8)$ \\
\hline Number of leisure Intervals & $\begin{array}{c}-0.065 * * * \\
(0.010)\end{array}$ & $\begin{array}{c}-0.075 * * * \\
(0.010)\end{array}$ & $\begin{array}{c}-0.075 * * * \\
(0.016)\end{array}$ & $\begin{array}{c}-0.086 * * * \\
(0.009)\end{array}$ & $\begin{array}{c}-0.049 * * * \\
(0.014)\end{array}$ & $\begin{array}{c}-0.053 * * * \\
(0.014)\end{array}$ & $\begin{array}{l}-0.053 * \\
(0.027)\end{array}$ & $\begin{array}{c}-0.062 * * * \\
(0.018)\end{array}$ \\
\hline Leisure combined with work & $\begin{array}{c}-0.480 * * * \\
(0.106)\end{array}$ & $\begin{array}{c}-0.306 * * * \\
(0.105)\end{array}$ & $\begin{array}{c}-0.306 * * \\
(0.149)\end{array}$ & $\begin{array}{c}-0.226 * * \\
(0.101)\end{array}$ & $\begin{array}{c}-0.200 * * \\
(0.085)\end{array}$ & $\begin{array}{c}-0.154 * \\
(0.083)\end{array}$ & $\begin{array}{l}-0.154 \\
(0.111)\end{array}$ & $\begin{array}{l}-0.170 \\
(0.111)\end{array}$ \\
\hline Spouse present during activity & $\begin{array}{l}- \\
-\end{array}$ & $\begin{array}{l}- \\
-\end{array}$ & $\begin{array}{l}- \\
-\end{array}$ & $\begin{array}{l}- \\
-\end{array}$ & $\begin{array}{c}0.139 * * * \\
(0.035)\end{array}$ & $\begin{array}{c}0.197 * * * \\
(0.035)\end{array}$ & $\begin{array}{c}0.197 * * * \\
(0.066)\end{array}$ & $\begin{array}{c}0.231 * * * \\
(0.047)\end{array}$ \\
\hline Adults present during activity & $\begin{array}{l}- \\
-\end{array}$ & $\begin{array}{l}- \\
-\end{array}$ & $\begin{array}{l}- \\
-\end{array}$ & $\begin{array}{l}- \\
-\end{array}$ & $\begin{array}{c}0.430 * * * \\
(0.047)\end{array}$ & $\begin{array}{c}0.136 * * * \\
(0.049)\end{array}$ & $\begin{array}{l}0.136 * \\
(0.077)\end{array}$ & $\begin{array}{c}0.177 * * \\
(0.073)\end{array}$ \\
\hline Out-of-home leisure (Ref.: TV) & - & $\begin{array}{c}0.768 * * * \\
(0.065)\end{array}$ & $\begin{array}{c}0.768 * * * \\
(0.099)\end{array}$ & $\begin{array}{c}1.009 * * * \\
(0.067)\end{array}$ & - & $\begin{array}{c}0.697 * * * \\
(0.043)\end{array}$ & $\begin{array}{c}0.697 * * * \\
(0.080)\end{array}$ & $\begin{array}{c}1.101 * * * \\
(0.060)\end{array}$ \\
\hline Exercise (Ref.: TV) & $\begin{array}{l}- \\
-\end{array}$ & $\begin{array}{c}0.909 * * * \\
(0.070)\end{array}$ & $\begin{array}{c}0.909 * * * \\
(0.092)\end{array}$ & $\begin{array}{c}1.117 * * * \\
(0.073)\end{array}$ & - & $\begin{array}{c}1.105^{* * *} \\
(0.088)\end{array}$ & $\begin{array}{c}1.105 * * * \\
(0.106)\end{array}$ & $\begin{array}{c}1.702 * * * \\
(0.149)\end{array}$ \\
\hline In-home leisure (Ref.: TV) & $\begin{array}{l}- \\
-\end{array}$ & $\begin{array}{c}0.403 * * * \\
(0.054)\end{array}$ & $\begin{array}{c}0.403 * * * \\
(0.077)\end{array}$ & $\begin{array}{c}0.486 * * * \\
(0.052)\end{array}$ & $\begin{array}{l}- \\
-\end{array}$ & $\begin{array}{c}0.445 * * * \\
(0.051)\end{array}$ & $\begin{array}{c}0.445^{* * *} \\
(0.110)\end{array}$ & $\begin{array}{c}0.705^{* * * *} \\
(0.068)\end{array}$ \\
\hline Reading/Listening (Ref.: TV) & - & $\begin{array}{c}0.185 * * * \\
(0.066)\end{array}$ & $\begin{array}{c}0.185 * * \\
(0.082)\end{array}$ & $\begin{array}{c}0.190 * * * \\
(0.063)\end{array}$ & - & $\begin{array}{c}0.449 * * * \\
(0.068)\end{array}$ & $\begin{array}{c}0.449 * * * \\
(0.096)\end{array}$ & $\begin{array}{c}0.584 * * * \\
(0.089)\end{array}$ \\
\hline Writing/Paperwork (Ref.: TV) & - & $\begin{array}{l}-0.122 * \\
(0.064)\end{array}$ & $\begin{array}{l}-0.122 \\
(0.083)\end{array}$ & $\begin{array}{c}0.033 \\
(0.064)\end{array}$ & - & $\begin{array}{l}-0.214 \\
(0.149)\end{array}$ & $\begin{array}{l}-0.214 \\
(0.184)\end{array}$ & $\begin{array}{l}-0.140 \\
(0.183)\end{array}$ \\
\hline Age & $\begin{array}{l}-0.023 * \\
(0.012)\end{array}$ & $\begin{array}{l}-0.010 \\
(0.012)\end{array}$ & $\begin{array}{l}-0.010 \\
(0.022)\end{array}$ & $\begin{array}{l}-0.005 \\
(0.011)\end{array}$ & $\begin{array}{c}0.020 \\
(0.014)\end{array}$ & $\begin{array}{c}0.019 \\
(0.014)\end{array}$ & $\begin{array}{c}0.019 \\
(0.040)\end{array}$ & $\begin{array}{c}0.030 \\
(0.019)\end{array}$ \\
\hline Age Squared & $\begin{array}{l}0.027^{*} \\
(0.014)\end{array}$ & $\begin{array}{c}0.015 \\
(0.014)\end{array}$ & $\begin{array}{c}0.015 \\
(0.026)\end{array}$ & $\begin{array}{c}0.010 \\
(0.013)\end{array}$ & $\begin{array}{l}-0.010 \\
(0.017)\end{array}$ & $\begin{array}{l}-0.009 \\
(0.016)\end{array}$ & $\begin{array}{l}-0.009 \\
(0.048)\end{array}$ & $\begin{array}{l}-0.015 \\
(0.022)\end{array}$ \\
\hline Children $<5$ in household & $\begin{array}{c}0.171 * * * \\
(0.044)\end{array}$ & $\begin{array}{c}0.190 * * * \\
(0.044)\end{array}$ & $\begin{array}{c}0.190 * * * \\
(0.061)\end{array}$ & $\begin{array}{c}0.181 * * * \\
(0.042)\end{array}$ & $\begin{array}{c}0.276^{* * * *} \\
(0.045)\end{array}$ & $\begin{array}{c}0.261 * * * \\
(0.044)\end{array}$ & $\begin{array}{c}0.261 * * \\
(0.107)\end{array}$ & $\begin{array}{c}0.265 * * * \\
(0.058)\end{array}$ \\
\hline Children 5-17 in the household & $\begin{array}{c}0.036 \\
(0.023)\end{array}$ & $\begin{array}{c}0.027 \\
(0.023)\end{array}$ & $\begin{array}{c}0.027 \\
(0.042)\end{array}$ & $\begin{array}{c}0.028 \\
(0.023)\end{array}$ & $\begin{array}{c}0.024 \\
(0.042)\end{array}$ & $\begin{array}{c}0.001 \\
(0.042)\end{array}$ & $\begin{array}{c}0.001 \\
(0.097)\end{array}$ & $\begin{array}{l}-0.011 \\
(0.056)\end{array}$ \\
\hline Working full-time & $\begin{array}{c}0.135 * * * \\
(0.045)\end{array}$ & $\begin{array}{c}0.103 * * \\
(0.044)\end{array}$ & $\begin{array}{c}0.103 \\
(0.083)\end{array}$ & $\begin{array}{c}0.092 * * \\
(0.044)\end{array}$ & $\begin{array}{c}0.061 \\
(0.047)\end{array}$ & $\begin{array}{c}0.052 \\
(0.046)\end{array}$ & $\begin{array}{c}0.052 \\
(0.140)\end{array}$ & $\begin{array}{c}0.019 \\
(0.062)\end{array}$ \\
\hline Working part-time & $\begin{array}{c}0.058 \\
(0.076)\end{array}$ & $\begin{array}{c}0.018 \\
(0.075)\end{array}$ & $\begin{array}{c}0.018 \\
(0.130)\end{array}$ & $\begin{array}{l}-0.001 \\
(0.074)\end{array}$ & $\begin{array}{c}0.190 * * * \\
(0.056)\end{array}$ & $\begin{array}{c}0.155 * * * \\
(0.055)\end{array}$ & $\begin{array}{c}0.155 \\
(0.119)\end{array}$ & $\begin{array}{c}0.191 * * \\
(0.076)\end{array}$ \\
\hline Female & $\begin{array}{c}0.112 * * * \\
(0.039)\end{array}$ & $\begin{array}{c}0.131 * * * \\
(0.039)\end{array}$ & $\begin{array}{l}0.131 * \\
(0.069)\end{array}$ & $\begin{array}{c}0.181 * * * \\
(0.038)\end{array}$ & $\begin{array}{c}0.067 \\
(0.043)\end{array}$ & $\begin{array}{c}0.085 * * \\
(0.042)\end{array}$ & $\begin{array}{c}0.085 \\
(0.118)\end{array}$ & $\begin{array}{l}0.102 * \\
(0.057)\end{array}$ \\
\hline Constant & $\begin{array}{c}8.707^{* * *} * \\
(0.229)\end{array}$ & $\begin{array}{c}8.264 * * * \\
(0.228)\end{array}$ & $\begin{array}{c}8.264 * * * \\
(0.395)\end{array}$ & - & $\begin{array}{c}7.278 * * * \\
(0.293)\end{array}$ & $\begin{array}{c}6.939 * * * \\
(0.288)\end{array}$ & $\begin{array}{c}6.939 * * * \\
(0.741)\end{array}$ & - \\
\hline N Clusters & - & - & 2051 & - & - & - & 696 & - \\
\hline Multiple R & 0.01 & 0.04 & 0.04 & 0.02 & 0.02 & 0.06 & 0.06 & 0.04 \\
\hline Observations & 9,648 & 9,648 & 9,648 & 9,648 & 8,580 & 8,580 & 8,580 & 8,580 \\
\hline
\end{tabular}

Note: Standard errors in parentheses.

Source: Sample consists of respondents between 21 and 65 from AHTUS 1985 (the US) and Unilever 1986 (the UK).

a. We estimate the following equation: $E_{i, j}=\beta_{1} I_{i, j}+\beta_{2} X_{i}+\beta_{3} A_{i, j}+\varepsilon_{i, j}$ where $E_{i t}$ is enjoyment rating for activity "i", $\mathbf{I}_{\mathrm{i}, \mathrm{j}}$ is a vector of leisure-quality indicators, $\mathbf{X}_{\mathbf{i}}$ is a vector of demographic controls, and $\mathbf{A}_{\mathbf{i}, \mathbf{j}}$ is a vector of dummy variables to control for the nature of leisure activity (ref.: TV Watching). Columns (1) and (5) show, for the US and the UK respectively, the results of estimating an OLS model controlling for demographics only, Columns (2) and (6) the results of an OLS model controlling for demographics and the nature of leisure activities, and Columns (3) and (7) are equivalent to (2) and (6) when clustering by respondent. Columns (4) and (8) present the formally more appropriate ordered logistic equations. 'Leisure combined with work' is defined as primary leisure combined with secondary market or non-market work.

${ }^{\mathrm{b}}$ We use the duration weights to control for the duration of the activity.

$* p<.10 * * p<.05 * * * p<.01$ 